GEOHYDROLOGY OF THE LLOYD AQUIFER,

LONG ISLAND, NEW YORK

by Murray Garber

U.S. GEOLOGICAL SURVEY

Water-Resources Investigations

Report 85-4159

Syosset, New York

1986 


\section{UNITED STATES DEPARTMENT OF THE INTERIOR}

DONALD PAUL HODEL, Secretary

GEOLOGICAL SURVEY

Dallas L. Peck, Director

For additional information write to:

U.S. Geological Survey

5 Aerial Way

Syosset, New York 11791

Telephone: (516) 938-8830
Copies of this report may be purchased from:

U.S. Geological Survey Books and Open-File Reports Federal Center, B1dg. 41 Box 25425

Denver, Colorado 80225 (303) $236-7476$ 


\section{CONTENTS}

Abstract. . . . . . . . . . . . . . . . .... 1

Introduction. . . . . . . . . . . . . . . . . . . . . 1

Purpose and scope...................... 2

Location and physiography. . . . . . . . . . . . . 2

Previous work. . . . . . . . . . . . ......... 3

Acknowledgments. . . . . . . . . . . . . . . . . . 5

Geohydrologic setting . . . . . . . . . . . . . . . . . 5

Stratigraphy ........................... 5

Bedrock . . . . . . . . . . . . . . . . . . 6

Raritan Formation . . . . . . . . . . . . . . 6

Lloyd Sand Member................... 6

Clay member....................... 8

Post-Raritan deposits . . . . . . . . . . . . . . 11

Ground-water system. . . . . . . . . . . . . . . . 15

Hydrology of the Lloyd aquifer. . . . . . . . . . . . . . . 16

Hydraulic properties . . . . . . . . . . . . . . 16

Ground water ........................ 17

Recharge. . . . . . . . . . ........ 17

Movement of water.................. 18

Saltwater/freshwater interface................ 21

Potentiometric surface. ............... 21

Age of water......................... 23

Water use ...................... 23

Summary and conclusions................... 32

References cited. . . . . . . . . . .......... 33

\section{ILLUSTRATIONS}

Figure 1. Map showing major geographic features of Long Island and

location of study area. . . . . . . . . . . 2

2. Map showing major physiographic features of Long Island . - 3

3. Generalized geologic section of Long Island . . . . . 5

4-8. Map showing:

4. Surface configuration of bedrock. . . . . . . . 7

5. Surface configuration of Lloyd aquifer. . . . . . 9

6. Thickness of Lloyd aquifer. . . . . ..... 10

7. Surface configuration of clay member of Raritan

Formation. . . . . . ......... 12

8. Thickness of clay member of Raritan Formation . . . 13

9. Generalized section showing stratigraphic units in northwestern Nassau County . . . . . . . . . . . . 14

10. Profile of the water table, potentiometric surface at base of Magothy aquifer, and in Lloyd aquifer in 1963. . . .

11. Map showing estimated average water-table altitude under natural (predevelopment) conditions ......... 


\section{ILLUSTRATIONS (Continued)}

Page

Figure 12. Generalized hydrogeologic section showing general flow

13. Potentiometric-head difference between Magothy aquifer and Lloyd aquifer, January 1975 . . . . . . . . . 20

14. Map showing inferred potentiometric surface of Lloyd aquifer before development (about 1900) . . . . . . . 22

15. Map showing potentiometric surface of Lloyd aquifer: A, 1947; B, 1971; C, 1975; D, 1979. . . . . . . . . 24

16. Hydrogeologic section showing approximate time required for water to move from water table at the ground-water divide to points within the regional ground-water system of Long Island . . . . . . . . . . . . 28

17. Graph showing annual pumpage from the Lloyd aquifer in Queens and Nassau Counties, 1920-80 . . . . . . . .

18. Map showing areas of significant pumpage from the Lloyd aquifer in Nassau and Queens Counties, 1971 ...... .

\section{TABLE}

Table 1. Hydrogeologic units of Long Island and their water-bearing properties. . . . . . . . . . . . . . . . .

\section{CONVERSION FACTORS AND ABBREVIATIONS}

Multiply inch-pound unit

inch (in)
foot ( $\mathrm{ft}$ )
mile (mi)
square mile (mi ${ }^{2}$ )
gallon (gal)
million gallons (Mgal)
billion gallons
million gallons per
day (Mgal/d)
gallon per minute
(gal/min)
gallon per minute per
foot (gal/min/ft)
foot per day (ft/d)
foot squared per day
(ft $2 / \mathrm{d}$ )
foot per mile
(ft/mi)

\author{
by \\ 25.4 \\ 0.3048 \\ 1.61 \\ 2.59 \\ 3.785 \\ 3,785 \\ $3,785,000$ \\ 3,785 \\ 0.06309 \\ 0.207 \\ 0.3048 \\ 0.0929 \\ 0.1893
}

to obtain metric unit

millimeter (mm)
meter (m)
kilometer (km)
square kilometer $\left(\mathrm{km}^{2}\right)$
liter $(\mathrm{L})$
cubic meter $\left(\mathrm{m}^{3}\right)$
cubic meter $\left(\mathrm{m}^{3}\right)$
cubic meter per day
( $\left.\mathrm{m}^{3} / \mathrm{d}\right)$
1iter per second
$\quad(\mathrm{L} / \mathrm{s})$
1iter per second per
meter $((\mathrm{L} / \mathrm{s}) / \mathrm{m})$
meter per day (m/d)
meter $\mathrm{squared}$ per day
$\quad\left(\mathrm{m}^{2} / \mathrm{d}\right)$
meter per $\mathrm{kilometer}$
$\quad(\mathrm{m} / \mathrm{km})$




\title{
GEOHYDROLOGY OF THE LLOYD AQUIFER, LONG ISLAND, NEW YORK
}

\author{
by Murray Garber
}

\begin{abstract}
The Lloyd aquifer contains only about 9 percent of the water stored in Long Island's ground-water system but is the only source of potable water for several communities near the north and south shores. The Lloyd aquifer is virtually untapped throughout most of central Long Island because current legal restrictions permit its use only in coastal areas.

The upper surface of the Lloyd aquifer ranges in depth from 100 feet below land surface on the north shore to more than 1,500 feet on the south shore. Aquifer thickness increases southward from 50 feet to about 500 feet. Transmissivity ranges from 1,500 to 19,000 feet squared per day. All recharge (35 to 40 million gallons per day) and nearly all discharge is through the overlying confining unit. Nearly all of the pumpage (approximately 20 million gallons per day) is in Queens and along the north and south shores of Nassau County.

Potable water can be obtained on most of Long Island in larger quantities and at shallower depths from other aquifers than from the Lloyd. Local contamination of these other aquifers, however, may require at least temporary withdrawals from the Lloyd in noncoastal areas. Significant withdrawals from the Lloyd aquifer may lower the potentiometric surface and thereby induce landward movement of sea water into the aquifer in coastal areas.
\end{abstract}

\section{INTRODUCTION}

The Lloyd aquifer is the deepest of Long Island's several aquifers. These aquifers are the sole source of water supply for more than 3.1 million people in Nassau and Suffolk Counties. Continuous clay beds overlie the Lloyd and retard vertical movement of water between it and the overlying aquifers; this maintains a relatively high artesian pressure in the Lloyd, even in the coastal areas, and preserves its potability even where the overlying aquifers have been invaded by seawater.

Pumping from the Lloyd aquifer has been restricted (with rare exceptions) since about 1955 by executive order of the New York State Department of Envi ronmental Conservation (Anthony Candela, New York State Department of Environmental Conservation, oral commun., 1981) to the coastal areas of northern and southern Long Island, where in most places it is the only source of potable ground water. The most notable exception is in central Queens County, where the Jamaica Water Supply Company has been pumping 4 to $6 \mathrm{Mgal} / \mathrm{d}$ from the Lloyd since the mid-1930's. 
As a result of this limitation on draft, the Lloyd aquifer remains relatively undeveloped throughout central Long Island and could provide an alternative, although limited, source of fresh ground water if the shallower aquifers there become contaminated. Excessive pumpage could, however, jeopardize the coastal water supply by lowering the potentiometric surface and thereby inducing excessive landward movement of sea water into the aquifer.

In 1979, the Geological Survey began a 5-year study titled "Regional Aquifer System Analysis of the Northern Atlantic Coastal Plain." The objective of that study (Meisler, 1980) was to define the geologic, hydrologic, and geochemical framework of the coastal-plain aquifer system and to develop a predictive computer model to investigate the system's response to various applied stresses such as extended drought or increased development. The complexity of this study necessitated a large amount of data, especially for model formulation and testing. These data were obtained through several subregional studies that were begun concurrently with the regional study.

\section{Purpose and Scope}

This report describes the geology and hydrology of the Lloyd aquifer on Long Island. It presents data on the aquifer's lithology, stratigraphic position, recharge rates, hydraulic properties, potentiometric-surface altitude, water movement, water use, and position of the saltwater interface. The information presented herein is summarized from published reports.

\section{Location and Physlography}

Long Island is about 120 miles long, less than 20 miles wide in most places, and has a total area of about $1,400 \mathrm{mi}^{2}$. The island comprises the counties of Kings, Queens, Nassau, and Suffolk, and trends about $N 75^{\circ} \mathrm{E}$ along its major axis, which is nearly parallel to the Connecticut shore (fig. 1 ).

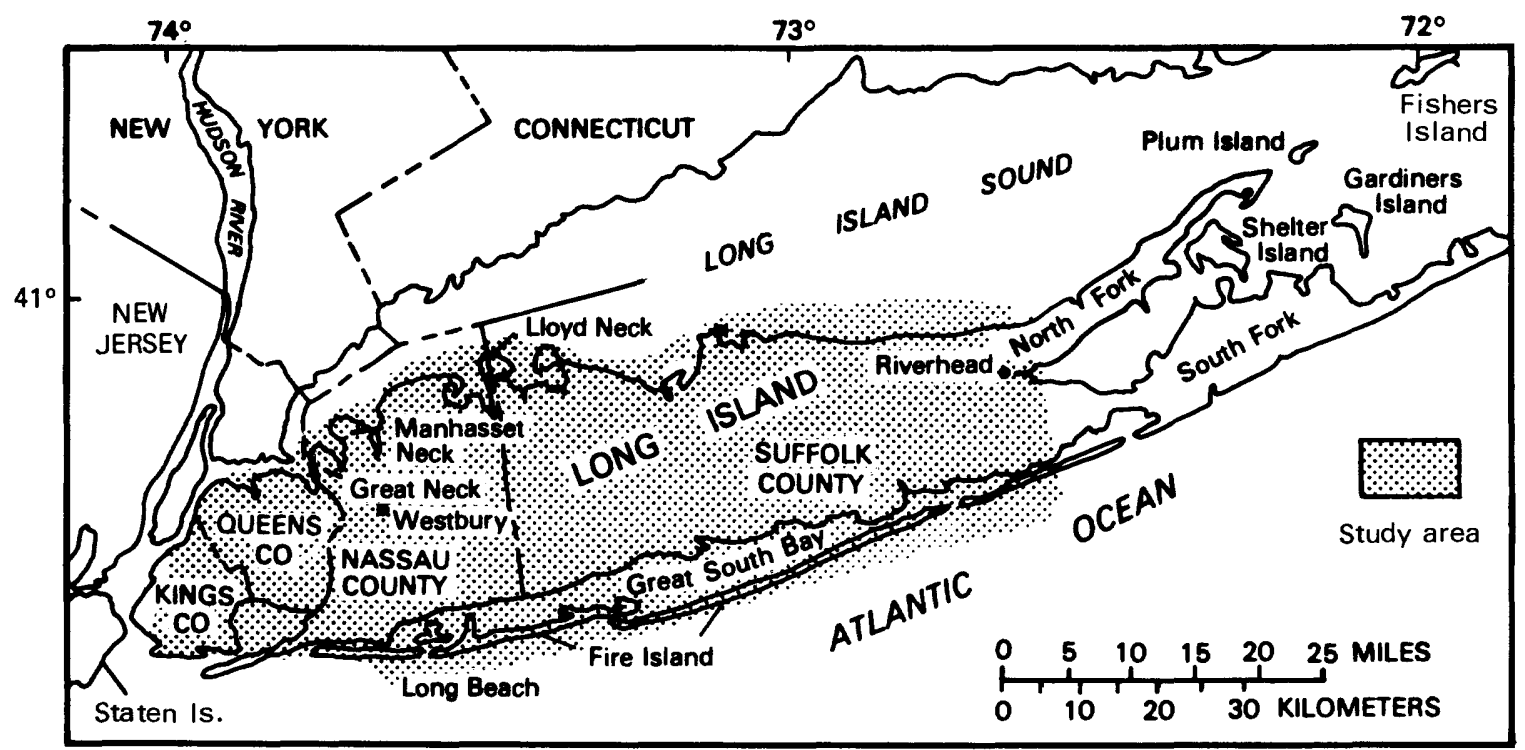

Figure 1 --Major geographic features of Long Island and location of study area. 
The area of study includes all of Queens and Nassau Counties and parts of Kings and Suffolk Counties. The study area ends at the north and south forks just east of Riverhead, where the Lloyd does not contain potable ground water. The Lloyd aquifer does not extend into northwestern Kings County and contains saltwater in the southwestern part of that county.

Long Island lies entirely within the Atlantic Coastal Plain physiographic province (Lobeck, 1939, p. 956). The topographic features of Long Island are largely the result of glacial activity during the Pleistocene Epoch. The important topographic features are a generally irregular and precipitous north shore; a bifurcated morainal-ridge system that forms the north and south forks in the east and joins in western Nassau County to form a single ridge through Queens and Kings Counties (fig. 2), a gently sloping outwash plain that extends from the central part of the island southward to the shore, and several disconnected barrier beaches along the south shore that enclose a series of shallow interconnected brackish bays.

The morainal ridges--the Harbor Hill and Ronkonkoma terminal moraines--represent the farthest southward advances of continental glaciation during the Pleistocene Epoch. The outwash plain consists of sheets of sand and gravel transported from the melting glaciers by streams. The steep headlands along the north shore and the barrier beaches along the south shore were formed by erosion and deposition by wave action during postglacial time.

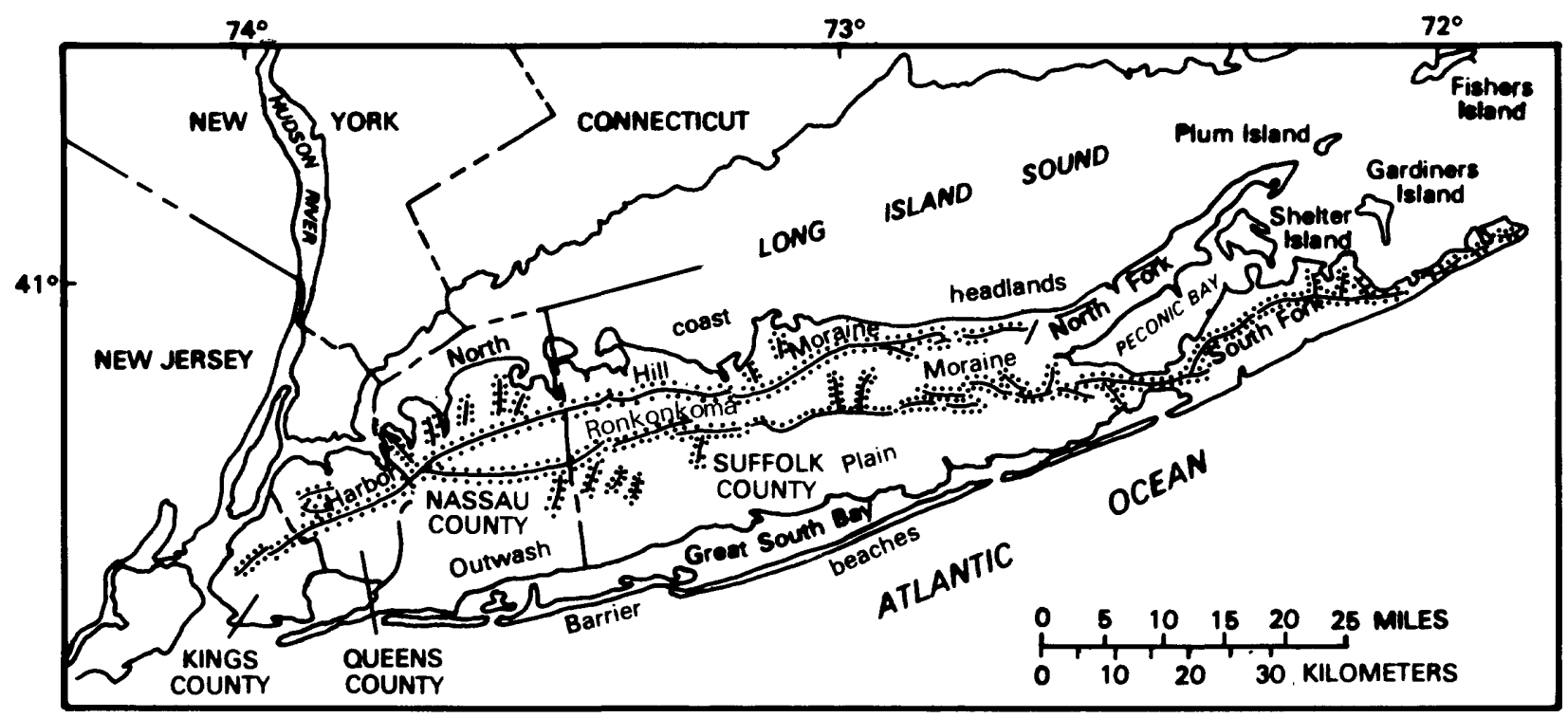

Figure 2.--Major physiographic features of Long Island. (Modified from Getzen, 1977, p. 7.)

\section{Previous Work}

The first comprehensive ground-water study of Long Island was published by Veatch and others (1906), who first used the name "Lloyd sand" to describe the material found in a well at Lloyd Neck (fig. 1) in northeastern Suffolk County. Fuller (1914) described the surficial geology of Long Island and included a thorough discussion of earlier published work on geology dating back to 1750. Suter (1937) evaluated the ground-water supply of Long Island 
and made estimates of the potential ground-water yield in each county. Suter and others (1949, p. 9) mapped the geologic units on Long Island and named the unit the Lloyd Sand Member, assigned it to the Raritan Formation, and referred to the overlying clay bed as the unnamed clay member of the Raritan Formation. The name Lloyd aquifer (in the Lloyd Sand Member) was first used by Cohen and others (1968, p. 18).

Several early contributions to the knowledge of the hydraulics of artesian aquifers were based on observations of the Lloyd aquifer on Long Island. Leggette (1937) investigated interference between pumping wells, and Jacob (1940, 1941) investigated the elastic properties of the Lloyd aquifer.

References to data compiled and published during 1936-62, including records of wells, we 11 logs, and water-leve 1 measurements in we1ls on Long Island, are listed at the end of this report.

Several reports on the hydrogeology of specific areas on Long Island have been published since the late 1950's. Among those that discuss the hydrogeology of the Lloyd aquifer are Perlmutter and Crandell (1959); Swarzenski (1959); Perlmutter and Geraghty (1963); Swarzenski (1963); Lubke (1964); Pluhowski and Kantrowitz (1964); Isbister (1966); Warren and others (1968); Soren (1971a, and 1971b); Jensen and Soren (1974); and Soren (1978).

Saltwater encroachment and the relationship between saltwater and freshwater in Long Island aquifers were described by Lusczynski and others (1956); Perlmutter and others (1959), Lusczynski and Swarzenski (1960, 1962, 1966); Lusczynski (1961, 1963); Isbister (1962); and Cohen and Kimme1 (1971).

Several reports summarizing the regional hydrology and the effects of population and industrial growth on the ground-water resources of Long Island have been published since the mid-1960's. Heath and others (1966) outlined successive phases of ground-water development; Cohen and others (1968) published an atlas of Long Island's water resources; Franke and Cohen (1972) estimated rates of ground-water movement; Franke and McClymonds (1972) summarized the hydrologic situation on Long Island and calculated hydraulic coefficients from examination of data from about 2,500 wells; and Kimmel (1973) evaluated the changes in potentiometric head in the Lloyd aquifer that have resulted from development. Franke and Getzen (1976) reported on results of cross-sectional analog model experiments to determine aquifer properties; Getzen (1977) presented a three-dimensional analog model of the Long Island aquifer system, and Reilly and Harbaugh (1980) provided a summary documentation of their digital conversion of Getzen's analog model.

The potentiometric surface of the Lloyd aquifer before development (about 1900) was estimated and mapped by Kimmel (1973). Other potentiometric maps of the Lloyd aquifer were prepared by the U.S. Geological Survey's Long Island staff for the years 1947 (Lusczynski, 1952), 1971 (Kimme1, 1973), 1975 (Rich and others, 1975), and 1979 (Donaldson and Koszalka, 1983b). Maps of the potentiometric surface of the Magothy aquifer that were used in this study are as follows: 1972 (Koch and Koszalka, 1973); 1975 (Prince, 1976), and 1979 (Donaldson and Koszalka, 1983a). Specific stratigraphic problems were addressed by Perlmutter and Todd (1965), Sirkin (1974), and Perry and others (1975). 


\section{Acknowledgments}

The author is indebted to Anthony Candela and Robert J. 0'Reilly of the New York State Department of Environmental Conservation for their assistance in providing information used in this report; to Thomas Casey of Henderson and Casey; and to Danie1 Davis, P.E., Superintendent, Water Department, Town of Hempstead, for samples and results of laboratory analyses of a deep test well at Roosevelt Field, Nassau County, N.Y.

\section{GEOHYDROLOGIC SETTING}

\section{Stratigraphy}

Long Island is underlain by unconsolidated sediments of Late Cretaceous and Pleistocene age that were deposited on a southeastward-sloping surface of crystalline basement rock ( $\mathrm{fig} \cdot 3$ ). The wedge-shaped sedimentary mass is mantled by sediments of Pleistocene and Holocene age that cover virtually all of Long Island.

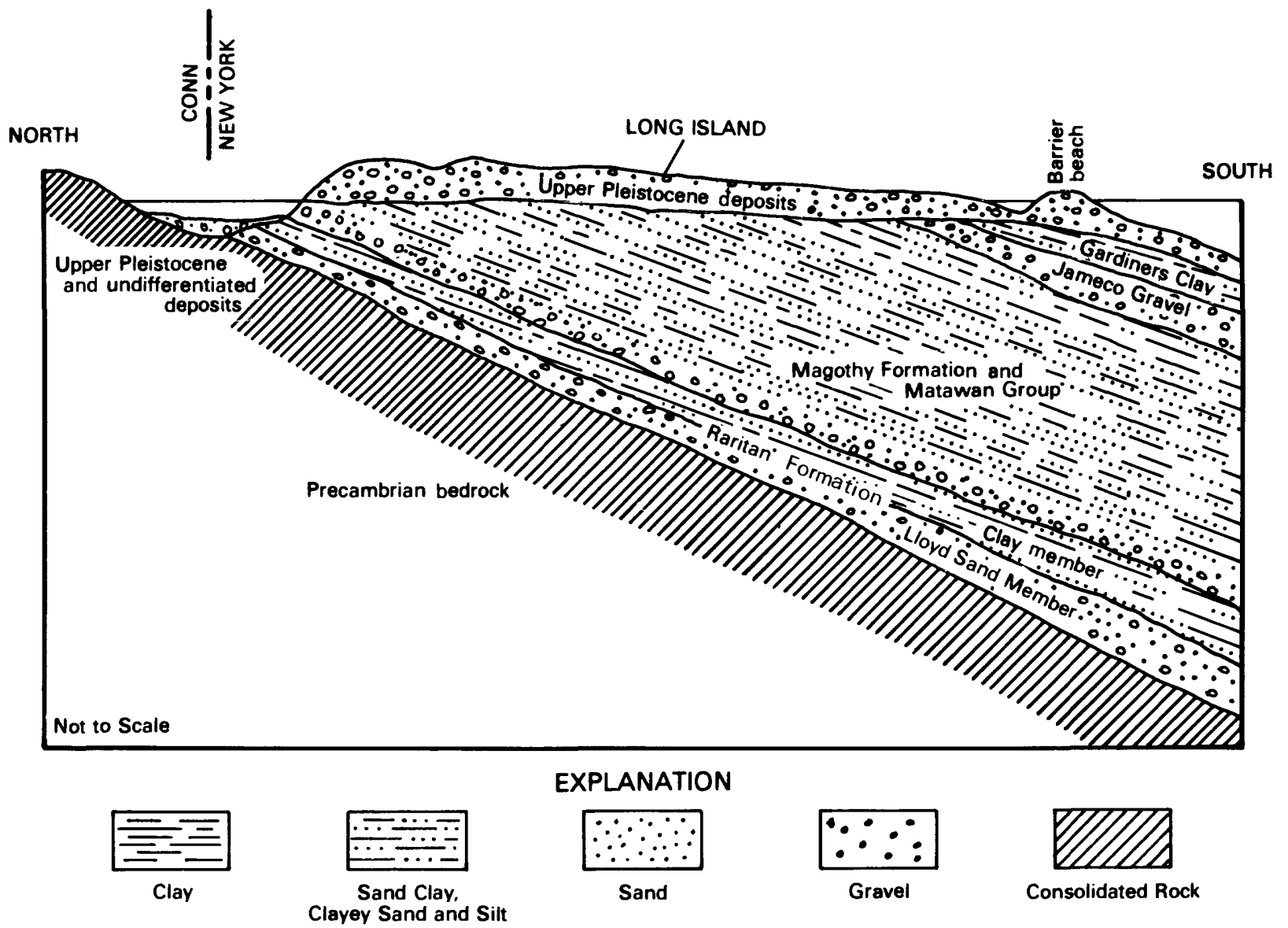

Figure 3.--Generalized geologic section of Long Island. (Modified from Cohen, Franke, and Foxworthy, 1968.) 


\section{Bedrock}

The consolidated bedrock that underlies Long Island consists almost entirely of igneous and metamorphic rock--predominantly gneiss and schist with local occurrences of granodiorite along the island's northwestern margin, and scattered intrusive bodies of granite and pegmatite (Suter and others, 1949, p. 13). The bedrock surface is nearly planar and slopes generally southeastward with a gradient of 65 to $100 \mathrm{ft} / \mathrm{mi}$. Bedrock depth ranges from land surface at a few locations in the northwest part of the island to about 2,000 ft below sea level on the south shore in western Suffolk County. A map showing the bedrock-surface altitude is given in figure 4. The bedrock surface beneath Long Island Sound, although not mapped in detail, maintains the general slope between Long Island and the New York and Connecticut mainland to the northwest.

A weathered zone overlies the bedrock surface in most places. This zone generally averages 20 to $30 \mathrm{ft}$ in thickness but can be as much as $100 \mathrm{ft}$ thick locally.

\section{Raritan Formation}

The Raritan Formation has been recognized in Cretaceous sediments as far south as central New Jersey (Perry and others, 1975, p. 1542). On Long Island, the Raritan Formation was deposited unconformably on the weathered bedrock surface and consists of the Lloyd Sand Member and an overlying unnamed clay member. The Raritan Formation as recognized in New Jersey consists of two sand members separated and capped by clay members. These are, in ascending order, the Farrington Sand Member, the Woodbridge Clay Member, the Sayerville Sand Member, and the South Amboy Fire Clay Member (Owens and others, 1970).

The stratigraphic correlation of the Raritan Formation of Long Island was revised by Sirkin in 1974. This work was based principally on palynological evaluation of core samples taken from a well (S21091) on Fire Island, a barrier island on Long Island's south shore (fig. 1). This well was drilled to a total depth of 2,014 ft and encountered weathered bedrock at a depth of $1,960 \mathrm{ft}$ below sea level. Stratigraphic correlations from Perlmutter and Todd (1965, p. 3) and Sirkin (1974, p. 439) are also shown on the well log. The contact between the Magothy and Raritan Formations in this well, as depicted by Perlmutter and Todd, was moved downward by Sirkin from 1,150 to $1,790 \mathrm{ft}$ below sea level, reducing Raritan thickness by about 80 percent from $810 \mathrm{ft}$ to $170 \mathrm{ft}$. Perry and others (1975, p. 1,540) expanded Sirkin's correlations by tracing equivalent units of the Raritan and Magothy Formations of New Jersey into the subsurface of Long Island.

The biostratigraphic units that Sirkin found in the Fire Island well cannot be easily identified or traced by lithologic means in other wells on Long Island. Accordingly, the lithostratigraphic units used in this report are those used in previous studies.

Lloyd Sand Member.--The Lloyd Sand Member was probably deposited as a series of braided streambeds and deltaic sediments. It consists of fine- to coarse-grained discontinuous sand and gravel beds with interbedded clay and 


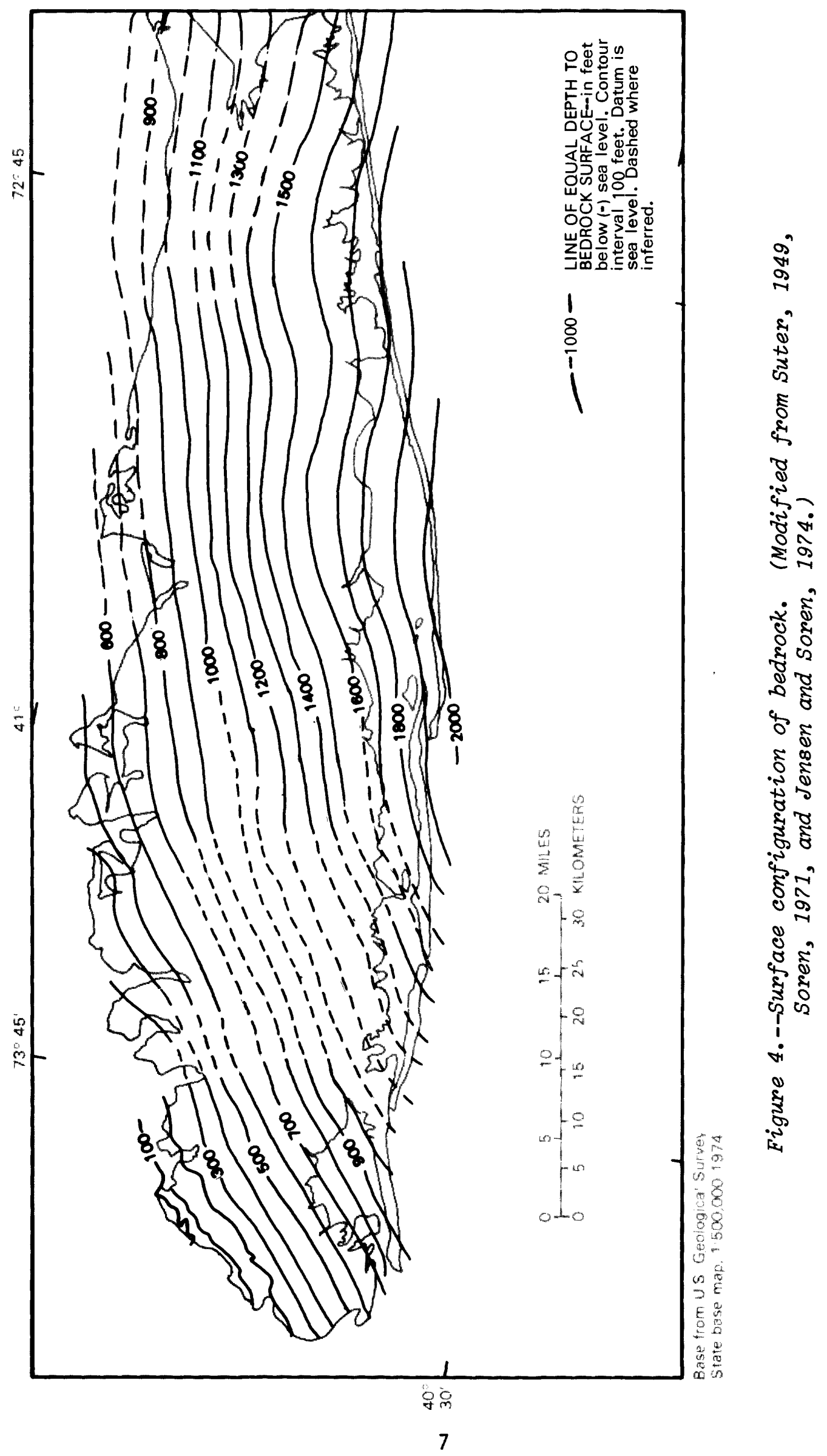


silt; the sand and gravel beds may contain varying amounts of interstitial clay and silt. The sand grains are generally clear or white but may also be gray or yellow. They may contain trace amounts of heavy minerals and, locally, lignite and iron oxide concretions.

No surface exposures of the Lloyd Sand Member have been found on Long Island. The sand member underlies most of the island and probably extends offshore beneath Long Island Sound in Suffolk County and the eastern part of Nassau County and to a considerable distance beyond the south shore. Its actual seaward extent beyond the south shore of Long Island is uncertain; marine seismic surveys show unconsolidated sediments of Cretaceous age extending at least $5 \mathrm{mi}$ beyond the barrier beaches (Mattick and Hennessy, 1980 , p. 23). Although the exact 1ithology of these deposits is unknown, it seems likely that the Lloyd Sand Member and the overlying clay member of the Raritan Formation are contained therein and extend several miles of fshore. The Lloyd Sand Member feathers out in western Long Island and has been thinned or removed by erosion and glaciation in northern Queens County and along the north shore of most of Nassau County. Post-Cretaceous erosion in northcentral Queens County produced a deeply incised valley in the sand member that was subsequently filled with sand and gravel deposits of Pleistocene age (Soren, 1971a, p. 19).

The Cretaceous deposits were partly removed from the northern margin of Nassau County by erosion during a pre-Wisconsinan stage, when sea level was much lower than at present (Swarzensk1, 1963, p. 14). They we re subsequently replaced by sand, gravel, and an overlying clay deposit that together appear to replicate the lithologic sequence of the Raritan Formation (Swarzenski, 1963, p. 11, 15, and 19). These deposits are of local importance and are discussed further on.

The Lloyd Sand Member lies at depths ranging from about $100 \mathrm{ft}$ below sea level in northern Queens County to more than 1,500 ft below sea level on the south shore of Suffolk County. Thickness ranges from 0 along the western boundary in parts of Kings and Queens Counties to more than $500 \mathrm{ft}$ in southwestern Suffolk County. The surface altitude and thickness of the sand member are shown in figures 5 and 6 , respectively.

Clay Member.--The unnamed clay member of the Raritan Formation overlies the Lloyd Sand Member throughout most of Long Island. It consists principally of laminated, silty, light- to dark-gray clays with intercalated sand lenses and lesser amounts of red, white, yellow, and mottled clays and carbonaceous clay with layers of lignite and pyrite (Suter and others, 1949, p. 17). The amount of intercalated sand increases southward. Absence of marine fossils and the presence of carbonized plant remains indicates a nonmarine depositional envi ronment.

The clay member of the Raritan Formation extends beneath most of Long Island, and outcrops of the upper few feet of the member have been found in parts of northern Queens County (Soren, 1978, p. 6, 1971, p1.1). Like the underlying Lloyd Sand Member, it is believed to extend a short distance offshore beneath Long Island Sound. The clay member, like the Lloyd Sand Member, probably extends southeastward from the south shore, but its sand content increases southward and may be as much as 50 percent in the area of Fire Island (fig. 1). 


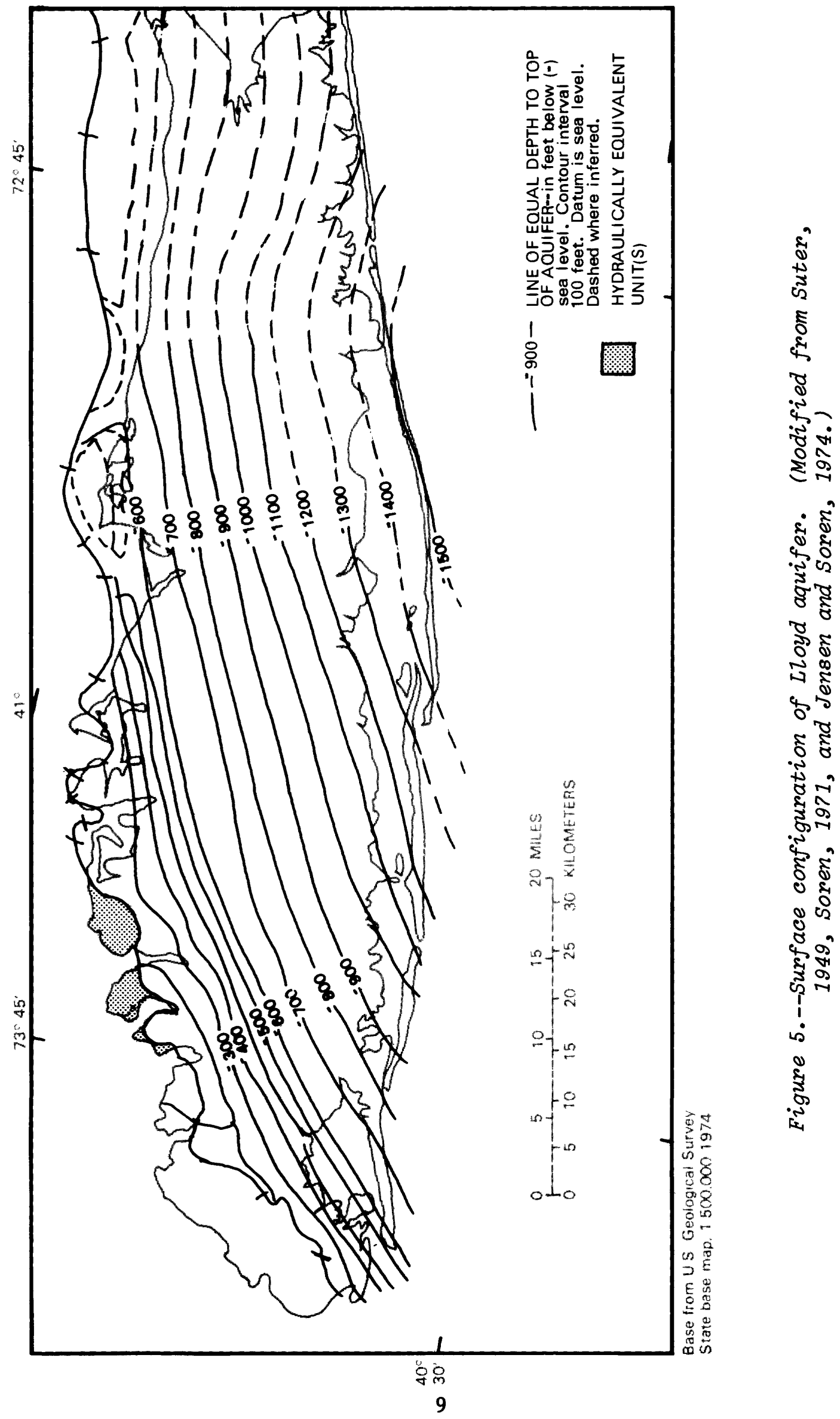




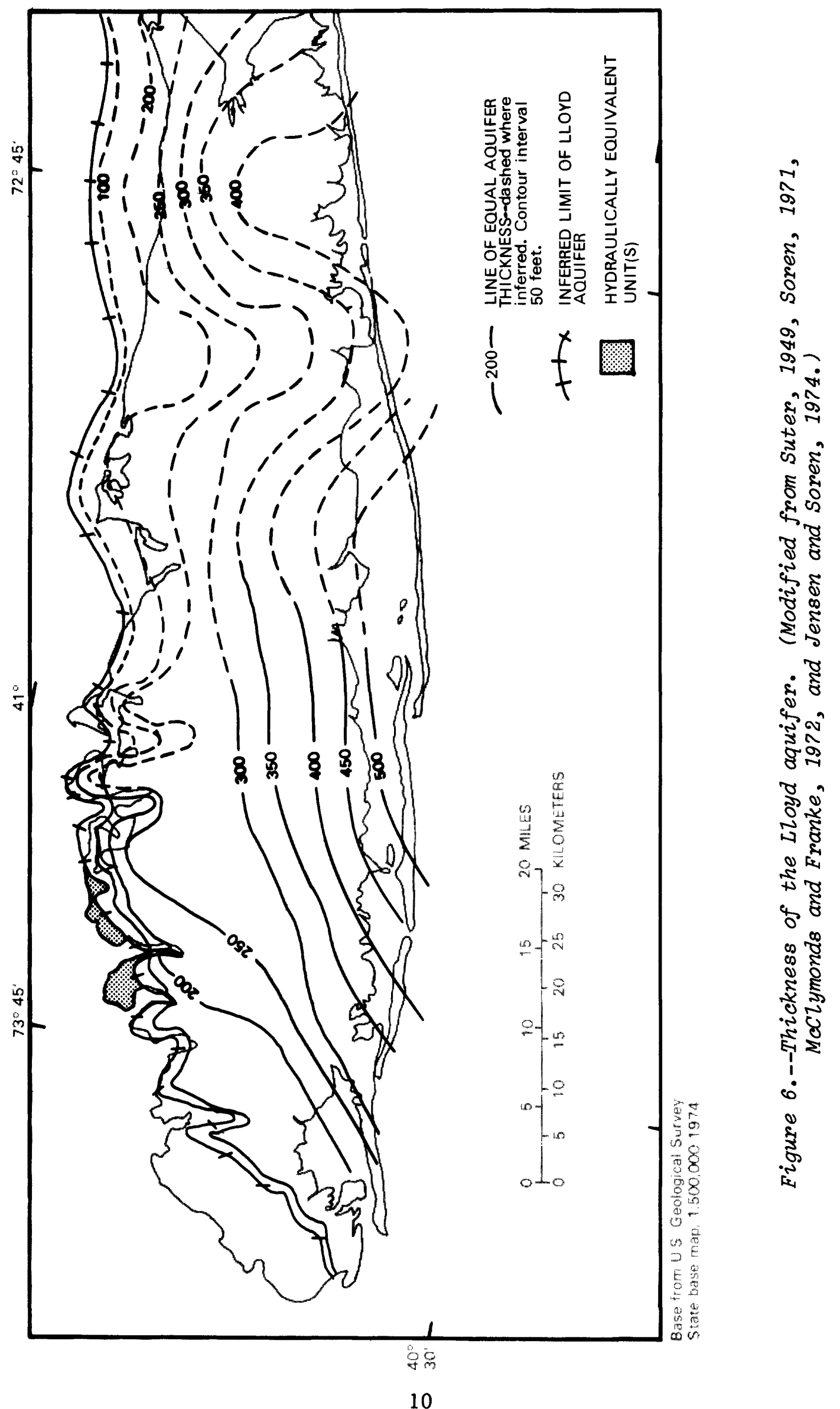


The clay member thins out in western Long Island (Buxton and others, 1981 , p. 7) and has been removed in central and northern Queens County and northern Nassau County by post-Cretaceous erosion. The clay member is absent in the previously discussed narrow, north-trending valley through central Queens County; here the Lloyd Sand Member is overlain directly by postCretaceous valley fill.

The clay member occurs at depths ranging from several feet above sea level where it crops out in northern Queens County to more than $1,200 \mathrm{ft}$ below sea level in south-central Suffolk County. Thickness of the clay member ranges from 150 to $250 \mathrm{ft}$ throughout most of Long Island and thins near the north and west margins of the island. The surface altitude and thickness of the clay member are shown in figures 7 and 8 , respectively.

\section{Post-Raritan Deposits}

Sediments of the Cretaceous Magothy Formation and overlying Matawan Group were deposited unconformably on the Raritan surface. Magothy and Matawan sediments are conformable and have not been differentiated on Long Island. They consist of as much as $1,100 \mathrm{ft}$ of fine- to medium-grained quartzose sand, silt, clay, and gravel beds that were deposited in a nonmarine environment, probably as deltaic and lagoonal-estuarine sediments (Perlmutter and Todd, 1965, p. 3). Magothy and Matawan sediments occupy most of Long Island except in western and northern Kings County, northern Queens County, parts of central Queens County, and parts of the northern margins of Nassau and Suffolk Counties.

These deposits have considerable relief (Suter and others, 1949, pl. XVII, XVIII; Jensen and Soren, 1974), especially in the western and north-central parts of Long Island, where extensive erosion occurred during the Pleistocene epoch. Where Magothy and Matawan deposits are absent, glacial deposits rest directly on the surface of the clay member of the Raritan Formation.

Marine deposits of the Monmouth Group unconformably overlie the Matawan Group (Jensen and Soren, 1974) in a narrow band beneath the south shore of Suffolk County (not shown on fig. 3) and extend an unknown distance southward. They consist of about $200 \mathrm{ft}$ of dark-gray and black silty and sandy micaceous clay, greenish clay, and glauconitic sandy clay (Perlmutter and Todd, 1965, p. 4).

These Cretaceous sediments are covered by deposits of Pliocene(?), Pleistocene, and Holocene age. Pleistocene material was deposited on Long Island during glacial stades and interstades, possibly as old as Kansan age. Overlying the Pleistocene are Holocene deposits, which are found along the shores and in the valleys of some of the larger streams; these consist of beach and other shoreline deposits, salt-marsh deposits, and alluvial deposits. The subcrops of Cretaceous sediments and bedrock in Long Island Sound are probably covered by several feet of muddy Holocene deposits.

The Jameco Grave1, the oldest Pleistocene deposit on Long Island, is found in southern and central Kings and Queens Counties and in southwestern 


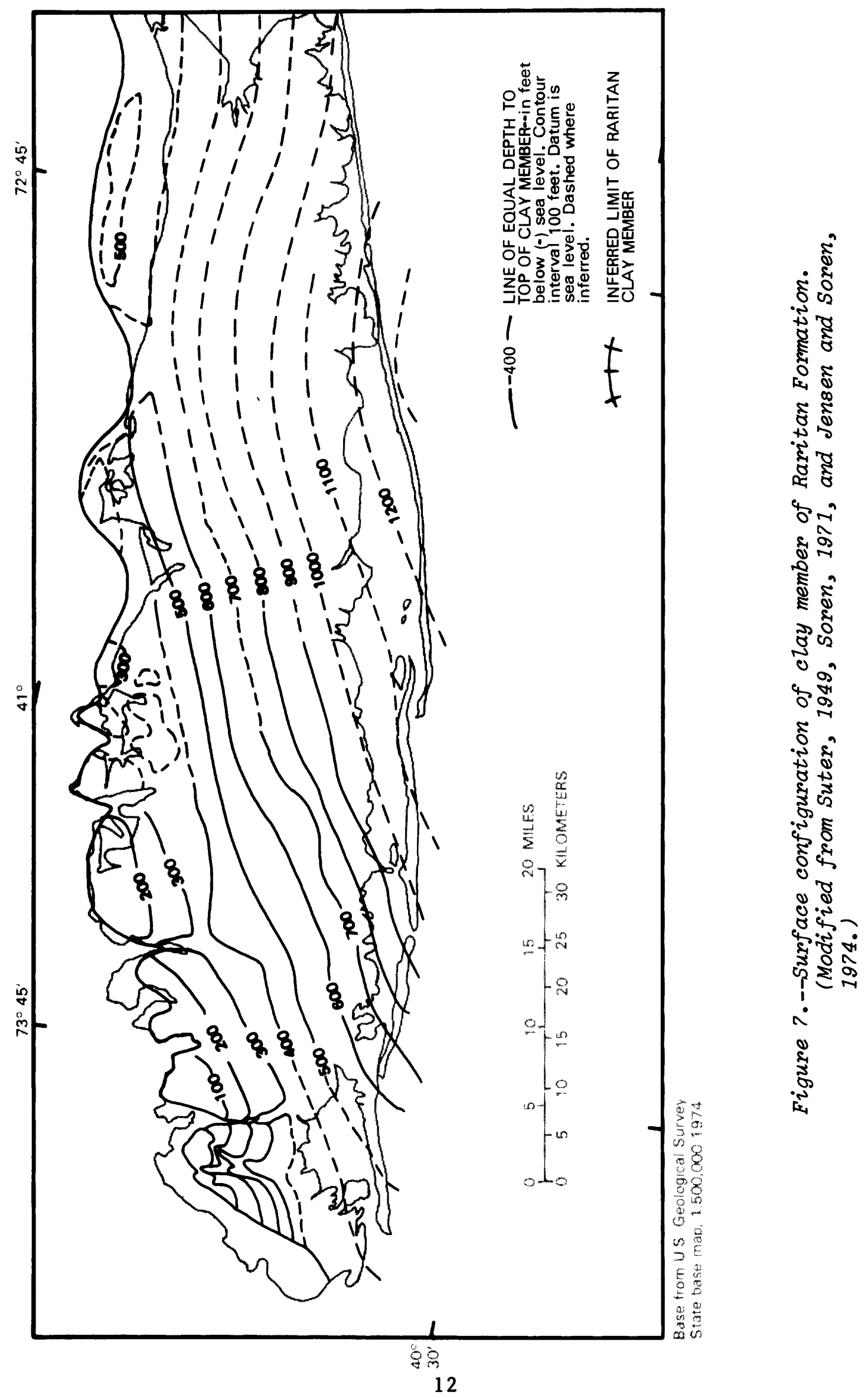




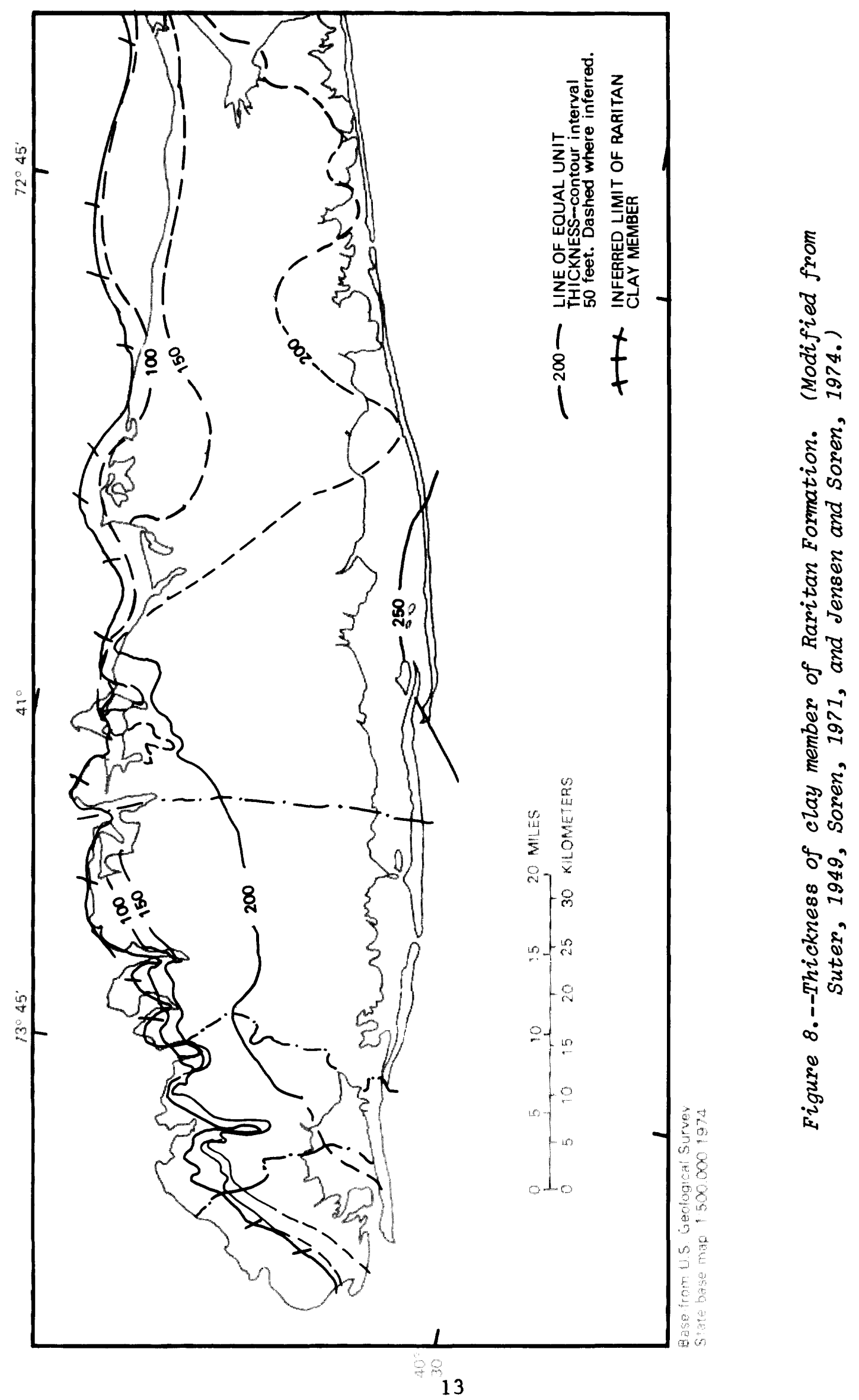


Nassau County. It unconformably overlies Magothy and Matawan sediments, where present, or the clay member of the Raritan Formation in the buried valley that cuts through central Queens County. The Jameco Gravel is pre-Sangamon in age, perhaps Kansan or Illinoian (Soren, 1971a, p. 8-9).

The Gardiners Clay, a marine interstadial deposit of Sangamon age, unconformably overlies and overlaps the Jameco in western Long Island and extends eastward along nearly the entire south shore of Long Island. The Gardiners Clay is found only in a narrow subsurface band extending no more than $10 \mathrm{mi}$ north of the barrier beaches. Its seaward extent is unknown.

Undifferentiated glacial deposits of Wisconsinan age blanket virtually a11 of Long Island. These consist of morainal and outwash deposits in the Harbor Hill and Ronkonkoma moraines.

On the northern margin of Nassau County, the Cretaceous sediments were deeply truncated by erosion during a pre-Wisconsinan stage of the Pleistocene, when sea level was much lower than at present. (Swarzenski, 1963, p. 14). Subsequent glacial deposition in that area resulted in a sand-and-gravel deposit with an overlying clay bed in juxtaposition with the Lloyd Sand Member and Raritan clay (fig. 9). Swarzenski (1963, p. 15) assigned these Pleistocene beds to the Jameco Gravel and Gardiners Clay. Seismic studies (Grim and others, 1970, p. 659-660) show sediments extending beyond the north shore into Long Island Sound; these sediments have a seismic character similar to that of the Cretaceous sediments of Long Island but are probably the Pleistocene sand, grave1, and clay described above.

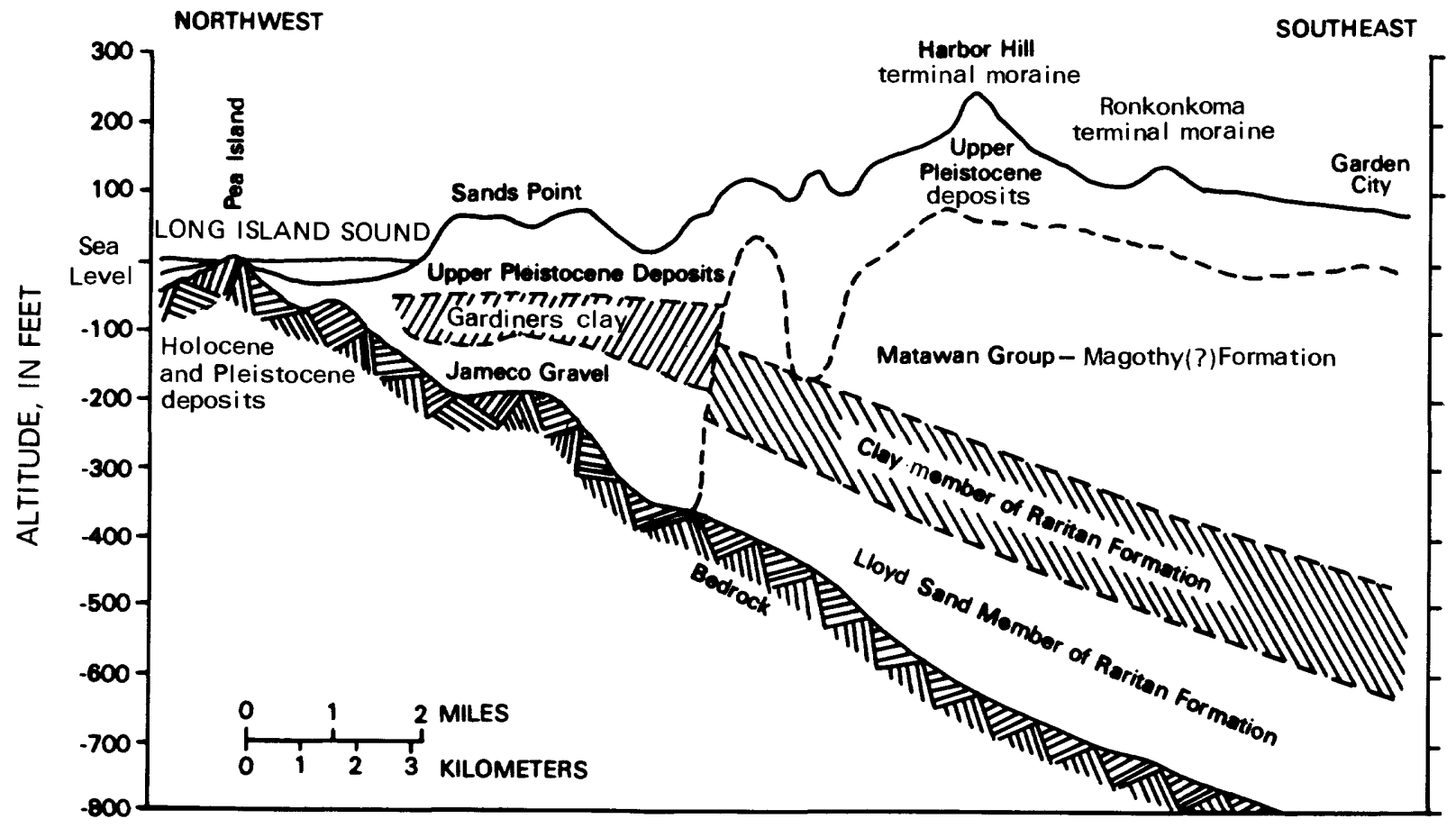

Figure 9.--Generalized section showing stratigraphic units in northwestern Nassau County, N.Y. (Modified from Swarzenski, 1963, p. 11.) 
These deposits are probably not contemporaneous with the main body of the Jameco and Gardiners to the south, however, because their composition is different--the Jameco Gravel deposits near the south shore contain abundant fragments of igneous and metamorphic rocks (Soren, 1978, p. 9), whereas the Jameco defined by Swarzenski (1963, p. 18) seems to be derived principally from Cretaceous deposits. If the Cretaceous sediments on the north shore of Long Island were truncated (as at present) before the deposition of the Jameco and Gardiners beds, and if the source area was to the north and northwest, as indicated by Swarzenski, the mineralogy of the main body to the south and the presumed outlier on the north would be similar, if not identical. Also, any deposits from an earlier glaciation to the north would probably have been destroyed by the advancing ice of the late Wisconsinan glaciation that formed the Harbor Hill and Ronkonkoma moraines. For these reasons, the Jameco and Gardiners (of Swarzenski) sediments in northern Nassau County are not contemporaneous with Jameco and Gardiners deposits to the south and were probably deposited during Wisconsinan time by detritus from nearby Cretaceous sediments filling depressions left by the advancing ice. Similar deposits have been found in other parts of the north shore.

Kilburn (1980) mapped these deposits in part of northern Nassau County and applied the hydrogeologic names Port Washington aquifer and Port Washingt on confining unit, respectively. The new names were applied to remove any allusion to correlation with Gardiners Clay and Jameco Grave1, and hydrogeologic terminology was used to include embedded outliers of the Lloyd Sand Member and clay member of the Raritan Formation.

\section{Ground-Water System}

The Long Island ground-water reservoir contains three extensive aquifers and several smaller aquifers of lesser thickness that have only local importance. Because the geology of Long Island has been described and mapped in lithostratigraphic terms and because little, if any, facies difference among units is recognized, the hydrologic units described below generally coincide with the lithostratigraphic units discussed in the previous section.

The three principal aquifers are the Lloyd, the Magothy, and the upper glacial aquifer. Of lesser thickness and areal extent are the Jameco aquifer, which is limited to Kings, Queens, and southwestern Nassau Counties, and the Port Washington aquifer (of Kilburn, 1980, formerly the Jameco of Swarzenski, 1963), which has been identified only in the north-central part of Nassau County. A similar deposit (the Jameco aquifer of Isbister, 1966) has been identified only in the northeastern part of Nassau County. The sediments of this unit are probably the stratigraphic equivalent of those of the Port Washington aquifer.

The Lloyd aquifer, as defined in this study, consists of the Lloyd Sand Member of the Raritan Formation and the confined contiguous sand beds of the Port Washington and Jameco(?) aquifers in northern Nassau County (fig. 9). Throughout most of Long Island, however, the Lloyd aquifer contains only the Lloyd Sand Member. 
Extensive clay units of relatively low permeability (confining layers or beds) impede flow between the subjacent and overlying aquifers, thus restricting flow mainly to the lateral direction within each aquifer. A major confining unit, the Raritan confining unit, which is the clay member of the Raritan Formation (fig. 3), separates the Lloyd from the overlying Magothy aquifer throughout Long Island. The Gardiners $\mathrm{Clay}$ separates the Magothy from the overlying upper glacial aquifer along the south coastal areas of Long Island (Getzen, 1977, p. 8 and 14). Table 1 (page 30) summarizes the rock units and their water-bearing properties.

The sedimentary deposits are saturated from the water table down to the nearly impermeable crystalline basement, but isolated lenses of perched water occur at or near land surface in surficial or buried depressions underlain by material of low permeability. Perched water is more common at higher altitudes on Long Island, where the water table tends to be farthest below land surface and clay beds tend to be more numerous.

Water moves downward through the zone of aeration mainly by gravity until it reaches the water table. Movement in the upper part of the saturated zone is principally lateral toward nearby points of discharge such as streams, seeps, or springs, but some of the water moves downward to recharge deeper aquifers. The movement of water in the saturated zone is governed by the hydraulic gradients and distribution of conductivity.

Almost everywhere on Long Island, water in the zone of saturation just below the water table is under unconfined conditions--that is, the water table can rise or fall according to changes in the balance between recharge and discharge. In contrast, where a saturated aquifer is capped by a layer of relatively impermeable material (a confining layer) that restricts vertical movement of water, the water is said to be under confined, or artesian, conditions. In general, water in the upper glacial aquifer and in the upper part of the Magothy aquifer is unconfined except where the unit is capped by the Gardiners Clay. Where the Magothy is not capped by the Gardiners Clay, it is a "leaky" system vertically and acts as a water-table aquifer. The Lloyd aquifer is confined over virtually its entire extent by the Raritan clay; thus, water in the Lloyd is under artesian pressure.

\section{HYDROLOGY OF THE LLOYD AQUIFER}

\section{Hydraulic Propertles}

Hydraulic conductivity, transmissivity, and storage coefficients of Long Island's aquifers have been calculated by many investigators. Methods used include interpretation of data from pumping tests, estimates based on data from specific-capacity tests, and interpretation of lithologic we 11 logs. The most thorough and systematic approach was that of McClymonds and Franke (1972), whose results are based on data from about 2,500 wells. The mean hydraulic-conductivity value for the Lloyd aquifer, based on their study of 132 wells, is $48 \mathrm{ft} / \mathrm{d}$, and mean transmissivity, based on a mean thickness of $240 \mathrm{ft}$, is $12,000 \mathrm{ft}^{2} / \mathrm{d}$. 


\section{Ground Water}

\section{Recharge}

Most of the recharge to the Lloyd occurs in areas where the water table is at high altitudes. It is at these locations that the vertical gradient is highest and a substantial downward component of flow is developed. Where the water table is highest, the potentiometric surfaces in the Lloyd and Magothy aquifers are also high, and because all aquifers on Long Island discharge directly or indirectly to the saltwater bodies surrounding the island, the potentiometric-surface configuration in the Magothy and Lloyd aquifers reflects that of the water table. The relationship between the water table and potentiometric surfaces of the Lloyd and Magothy is shown in profile in figure 10. The crest of the potentiometric surface of the Lloyd in this profile is about 4 miles north of the Magothy crest. Northward discharge from the Lloyd aquifer toward Long Island Sound is probably extremely small in this area. A map showing the water-table altitude before development (about 1900) is given in figure 11 .

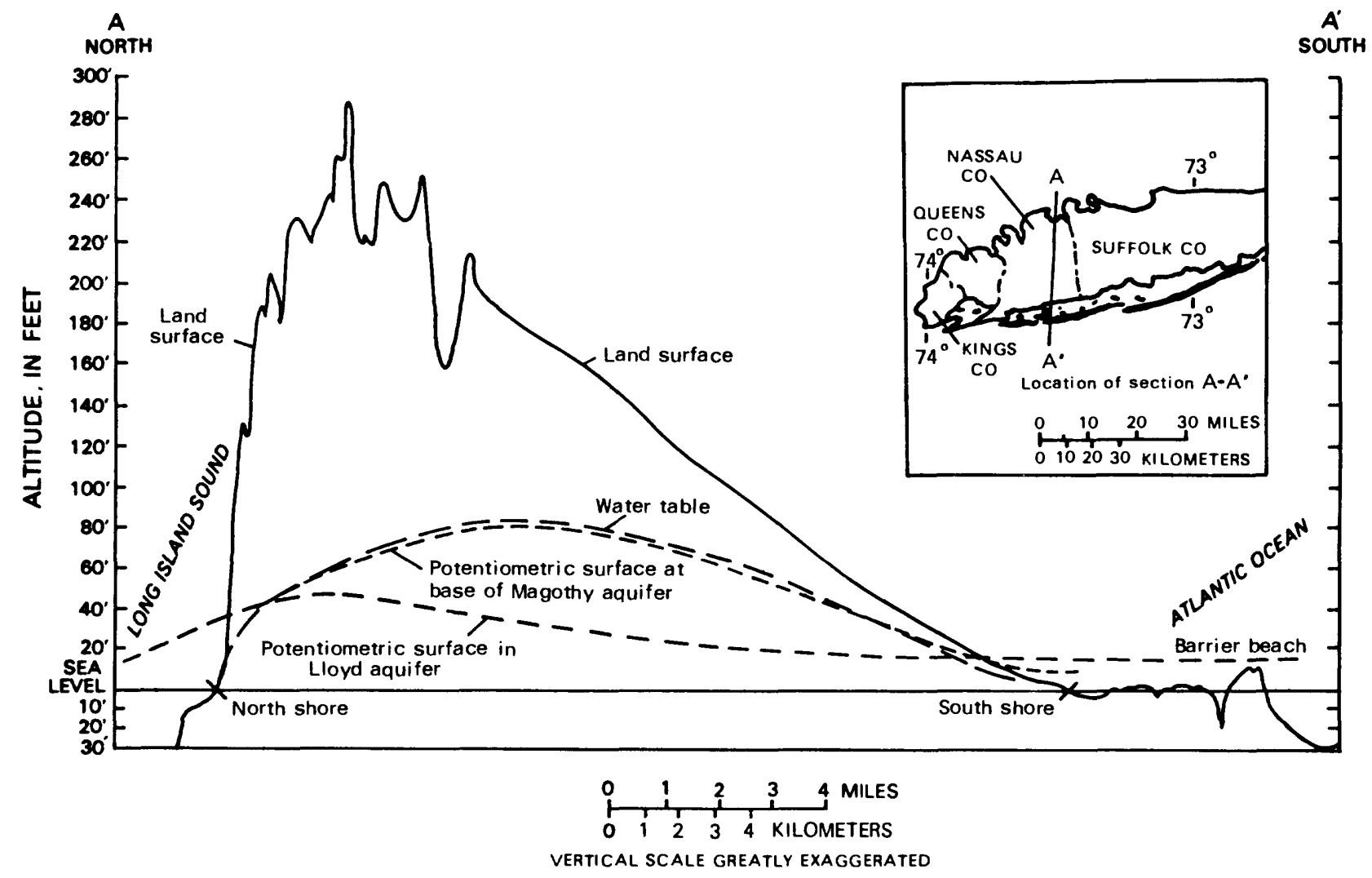

Figure 10.--Profile of the water table and potentiometric surface at base of Magothy aquifer and in Lloyd aquifer in 1963. (Modified from Franke and McClymonds, 1972, p. 26.) 


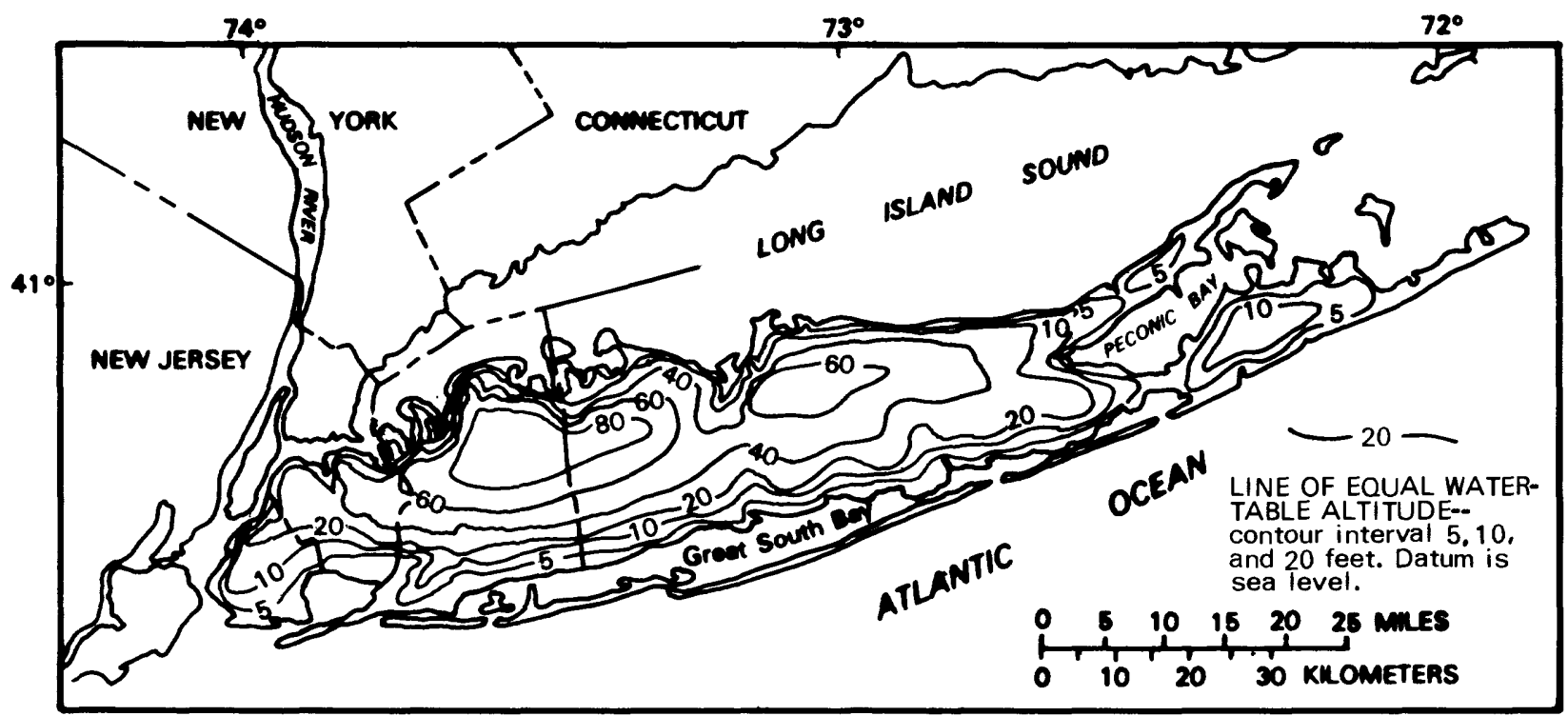

Figure 11.--Estimated average water-table altitude under natural (predevelopment) conditions, about 1900. (Modified from Franke and McClymonds, 1972, p. 13.)

\section{Movement of Water}

Flow through the aquifer system of Long Island is mainly lateral from the recharge area to near the points of discharge, then upward at the margins of the island and into the overlying sediments, Great South Bay, the ocean, or Long Island Sound (fig. 12). A small amount of water from the Magothy moves downward to recharge the Lloyd aquifer. Except for the area of the buried valley in Queens County, this is the only source of recharge to the Lloyd aquifer inasmuch as the Lloyd has no outcrop area to receive direct inflow.

Estimates of outflow from the principal aquifers indicate that the Lloyd aquifer discharges a relatively small percentage ( 9 percent) of the island's total fresh ground-water outflow (Franke and McClymonds, 1972, p. 33). The greatest outflow is from the Magothy aquifer ( 53 percent) and the upper glacial aquifer ( 38 percent). The low vertical hydraulic conductivity of the Raritan confining unit greatly restricts downward movement into the Lloyd, and the relatively low transmissivity in the Lloyd (only about $1 / 3$ that of the Magothy) does not permit a high rate of flow within the aquifer. The low vertical permeability of the Raritan confining unit also restricts upward movement of water from the Lloyd into the Magothy aquifer in areas where water levels in the Lloyd exceed those in the Magothy. This confining layer serves to maintain a potable water supply in the underlying Lloyd aquifer beneath the barrier beaches and along the south shore of Long Island, where the overlying aquifers contain brackish or saline water.

Natural discharge from the Lloyd aquifer by subsurface outflow was estimated to be about $40 \mathrm{Mgal} / \mathrm{d} \pm 25$ percent (Franke and McClymonds, 1972). This value is corroborated by results of mass-balance computations and by an estimate of recharge to the Lloyd calculated from potentiometric maps. Maps showing the potentiometric surface of the Magothy aquifer (Prince, 1976) and Lloyd aquifer (Rich, Prince, and Spinel1o, 1975) during March 1975 and January 
1975, respectively, were used to produce a map (fig. 13) showing the difference in hydraulic head between these two aquifers (Magothy head minus Lloyd head). The positive head difference represents the downward driving force for recharge to the Lloyd aquifer. The contour line representing equality of hydraulic head in the two aquifers (zero head difference) was established as the boundary of the area within which recharge to the Lloyd occurs. The area was divided into 13 concentric segments ranging from zero to $65 \mathrm{ft}$ of head differential, each representing an increment of $5 \mathrm{ft}$. The area of each segment was determined by planimeter. Flux was determined by a form of Darcy's Law, which states that flux through a given cross-sectional area is equal to the product of the hydraulic conductivity, gradient, and crosssectional area. For this application, the vertical hydraulic conductivity of the confining bed was assumed to range from 0.001 to $0.003 \mathrm{ft} / \mathrm{d}$; vertical gradient was assumed to be the mean head difference within each of the 13 segments, and the total cross-sectional area was the sum of the areas of each of the 13 segments. It was further assumed that the flow in the confining bed is at, or very nearly at, a steady-state condition. Total recharge to the Lloyd computed by this method ranges from about 12 to $35 \mathrm{Mgal} / \mathrm{d}$; actual recharge to the Lloyd is probably within the upper third of this range.

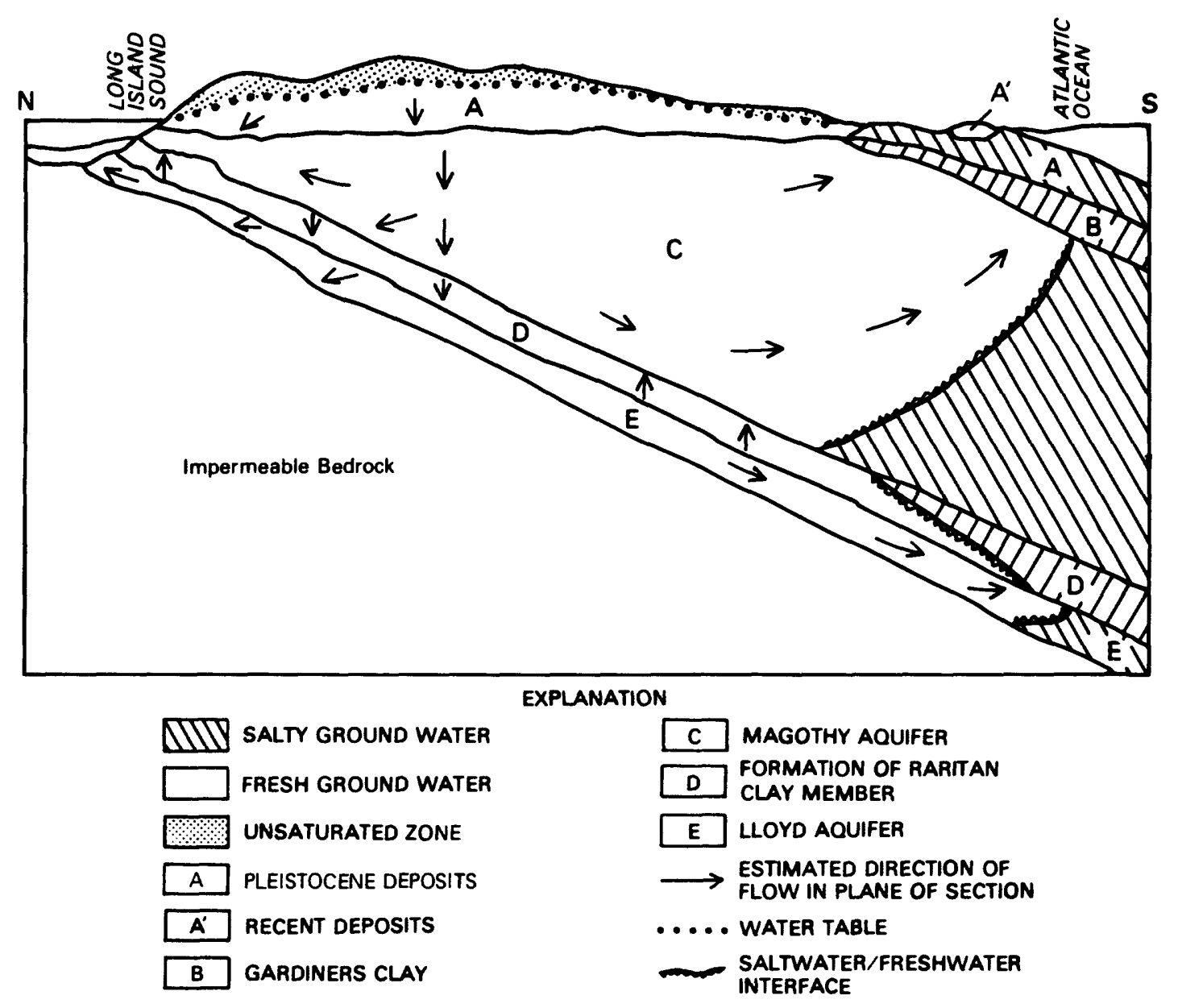

Figure 12.--Generalized hydrogeologic section showing general flow pattern within the Long Island aquifer system. 


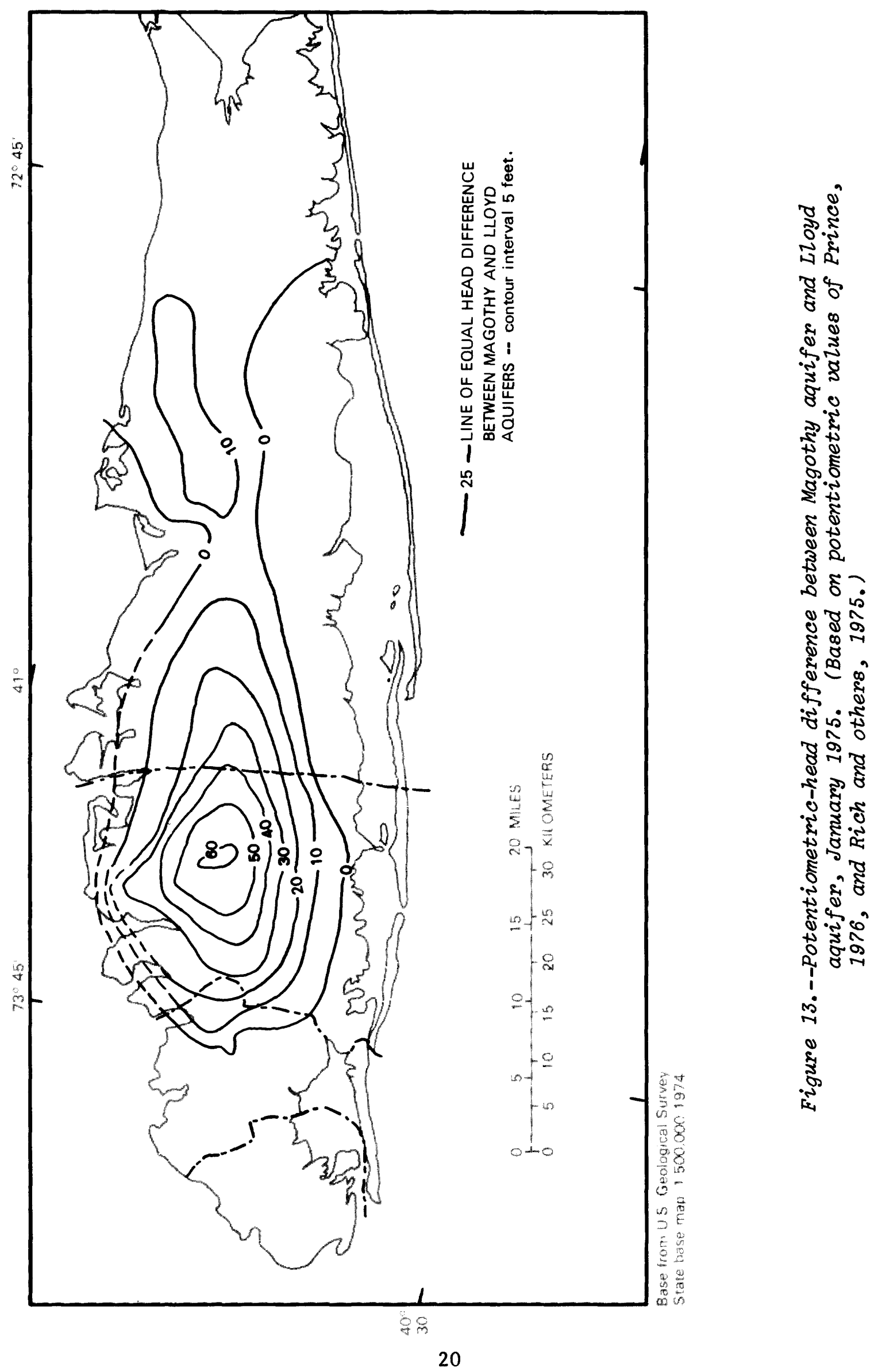




\section{Saltwater/Freshwater Interface}

Discharge from the Lloyd aquifer is generally upward through the confining bed to the overlying Magothy aquifer (fig.13). Seaward movement of freshwater in both the Magothy and Lloyd aquifers is constrained by the saltwater interface, a mixing zone that forms between waters of two different densities. Mixing occurs along such a zone by the mechanisms of cyclic flow (Cooper, 1964, p. 6; Cooper, 1959, p. 463), capillary forces, diffusion, and fluctuations in the position of the interface as a result of transient stresses and changes in storage; thus the contact between saline and freshwater is generally a zone of intermediate salinity rather than a sharp interface.

In general, the saltwater/freshwater interface in the Lloyd aquifer is offshore, but it has been drawn landward in Kings and Queens Counties as a result of extensive public-supply pumpage during the 1930's and 1940's.

\section{Potentiometric Surface}

The potentiometric-surface configuration of the Lloyd aquifer at any given time is dependent upon the balance between recharge, discharge, and changes in storage in the aquifer at that time, and is therefore also dependent upon the potentiometric-surface configuration of the overlying Magothy aquifer and the amount of water removed by pumping wells. The effects of Lloyd pumpage are mostly local, in contrast to those in the Magothy, which usually affect larger areas. In general, water levels in the Lloyd aquifer in the eastern two-thirds of Long Island have not changed significantly over the years, especially in relation to the western third of the island, where heavy pumpage from the Lloyd and overlying aquifers has created a deep cone of depression in Queens County and localized cones of depression in other localities. A slight depression in the potentiometric surface may have developed at Long Beach, and saltwater has been drawn landward in southern Queens and, to a lesser extent, on the Great Neck peninsula.

To represent the flow system of the Lloyd aquifer, it is necessary to know the approximate configuration of the potentiometric surface of both the Lloyd aquifer and basal part of the Magothy aquifer before the beginning of significant withdrawals. The inferred potentiometric-surface configuration of the Lloyd aquifer before development (about 1900) was reconstructed by Kimmel (1973) from the earliest available water-level data and adjusted where necessary for the effects of pumping. The configuration is shown in figure 14. Most of these early measurements were made between 1920 and 1940, when development in the western part of the island had been underway for decades. Although this map may contain minor errors or inconsistencies, it is probably a reasonable interpretation of predevelopment conditions and shows a pattern similar to that of today, except that it lacks the deep cone of depression from pumping in central Queens County and shows generally higher potentiometric levels throughout Nassau County. Water levels at Long Beach, for example, fell from about $12 \mathrm{ft}$ above sea level in 1923 to sea level in 1971. 


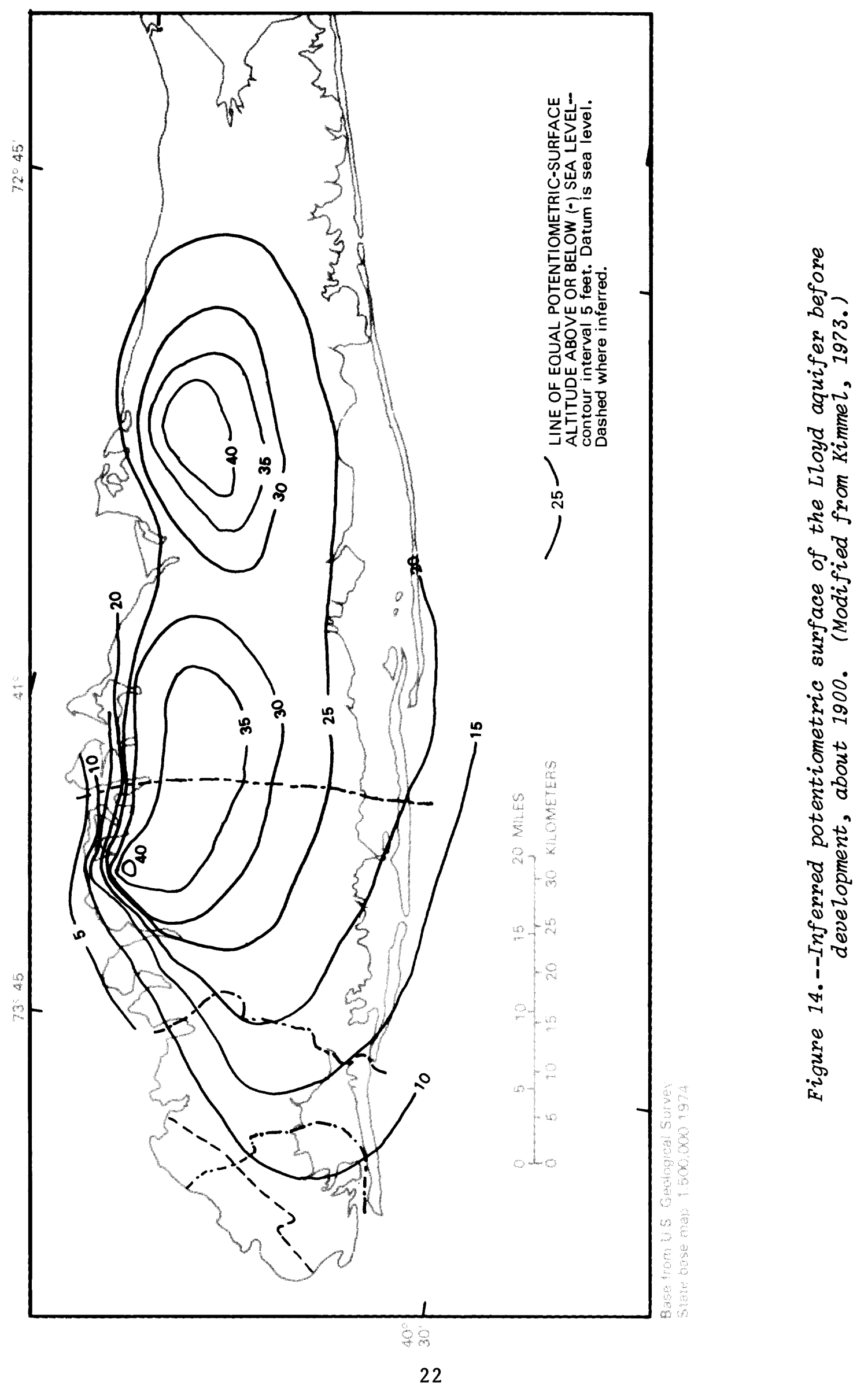


Maps of the potentiometric surface of the Lloyd aquifer in 1947, 1971, 1975, and 1979 are shown in figures 15A through 15D. Comparison of these maps shows the general trend of development of the Lloyd aquifer in the western part of Long Island.

\section{Age of Water}

Rates of ground-water movement derived from computations and analogmodel experiments (Franke and Cohen, 1972, p. 272) indicate a transit time of about 400 years for water to move from the water table to the Lloyd aquifer and about 3,000 years from the ground-water divide to the barrier beaches on the south shore, as indicated in figure 16. Vertical transit time through the Raritan confining layer was estimated to be 200 years. Any stable soluble contaminant that enters the Long Island ground-water system and moves at the same velocity as the ground water can be expected to reside within the system for at least these amounts of time.

\section{Water Use}

Nearly all pumping from the Lloyd aquifer is in Queens and Nassau Counties. At present, no wells are pumping water from the Lloyd aquifer in Kings County, and only a few in Suffolk County. Continuous records of pumpage from the Lloyd aquifer date back to about 1920; but the Lloyd was probably being tapped before the turn of the century (Veatch and others, 1906, p. 65).

Annual pumpage from the Lloyd aquifer in Nassau and Queens Counties over the period of record is depicted in figure 16. Pumpage in Kings and Suffolk Counties is not shown because it forms such a small percentage of the total and because these records are incomplete. Withdrawal records from industrial and other nonpublic users are unavailable, but withdrawals are estimated to be less than 20 percent of the total pumpage from the Lloyd aquifer. These withdrawals are dispersed throughout the county (Soren, 1971a, p. 26). In contrast, at least 80 percent of the total pumpage from the Lloyd is concentrated in the well fields of the Jamaica Water Supply Company within a relatively small area in central Queens County. That pumpage has a greater effect on the potentiometric surface of the Lloyd in western Long Island than that by any other company.

Pumpage from the Lloyd aquifer in Queens County has remained relatively stable over the period of record and ranges from 1.5 to 2.5 billion gallons per year or 4.1 to $6.8 \mathrm{Mgal} / \mathrm{d}$ ( $\mathrm{fig}$. 17). Use of Lloyd water in Nassau County, on the other hand, reflects the rapid expansion that took place after 1944 . For example, pumpage from the Lloyd aquifer nearly doubled from about 6.8 to 13.7 Mgal/d between 1944 and 1952. Stabilization since 1965 reflects the restrictions placed on the use of this aquifer.

The distribution of withdrawals in 1971 is shown in figure 18. The areas of greatest pumpage from the Lloyd aquifer are Long Beach ( 35 percent), central Queens ( 29 percent), and the Great Neck peninsula (16 percent); the remaining 20 percent is from wells along the north shore of Nassau County and from a few isolated wells in central Nassau County and northwestern Suffolk County that are not shown on this map. 


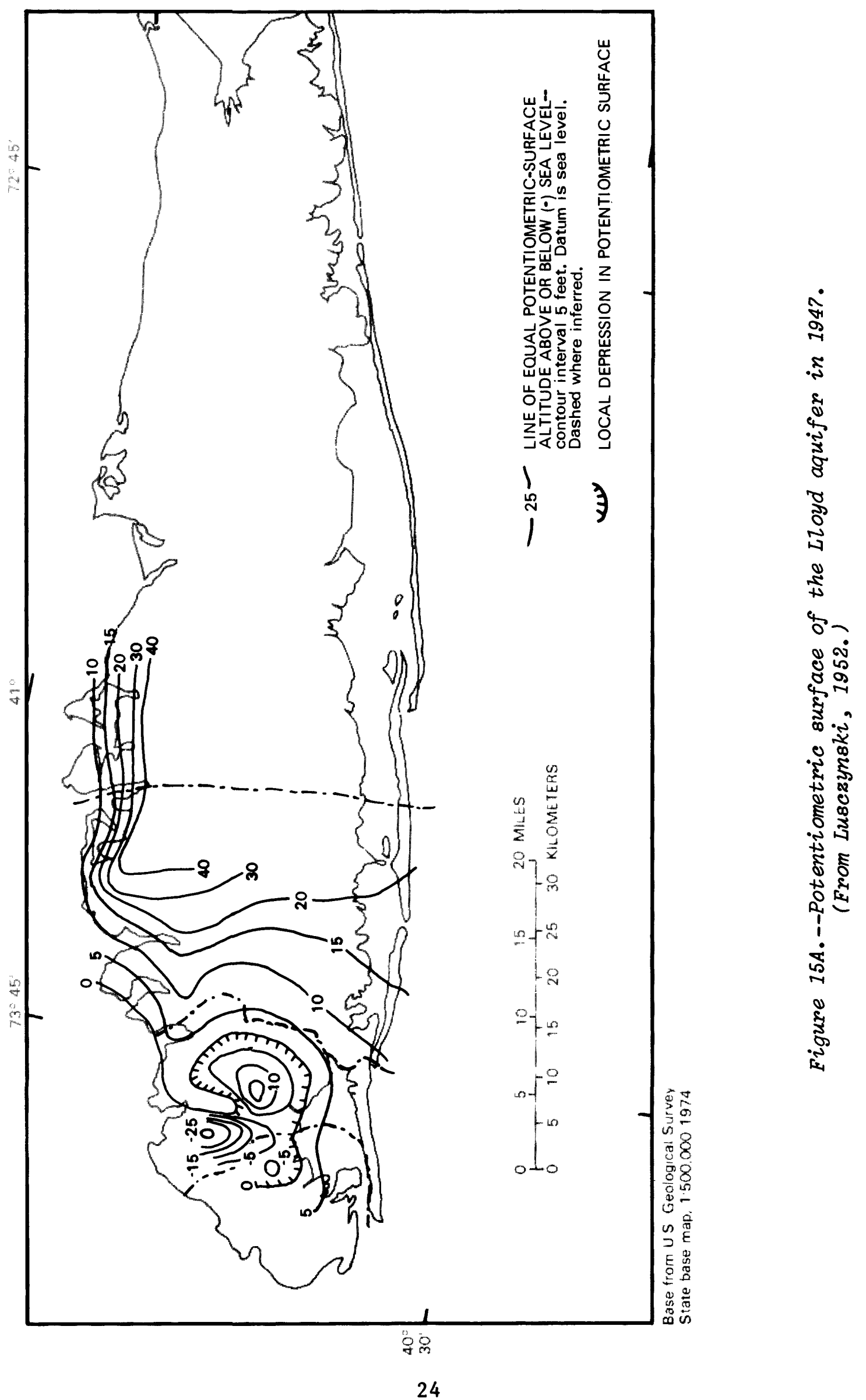




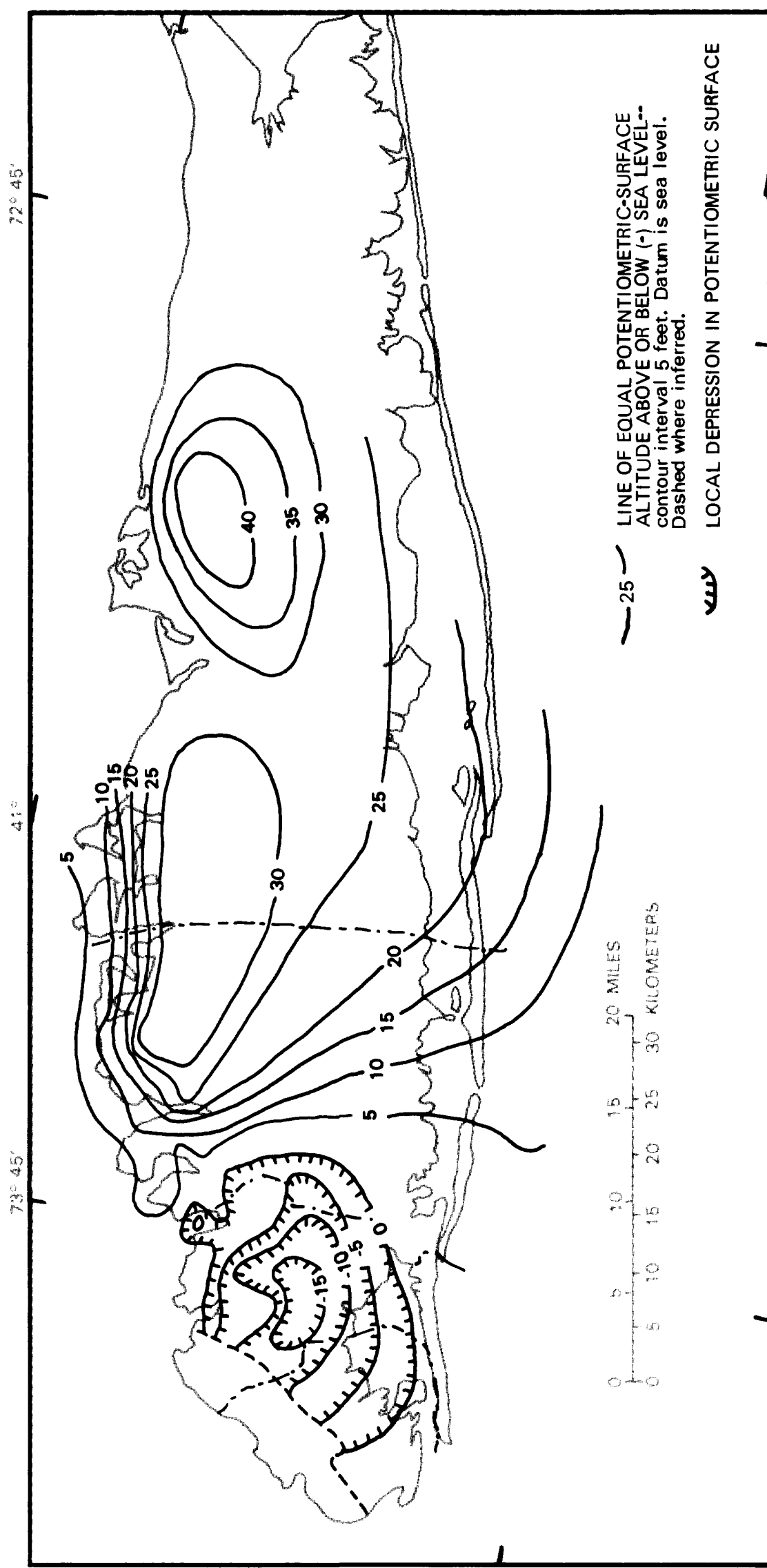

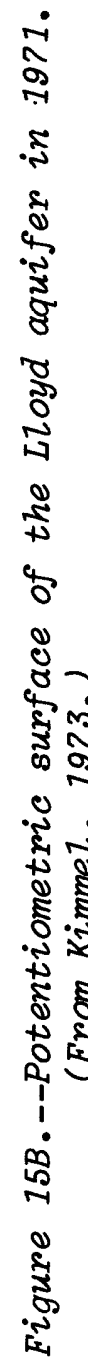




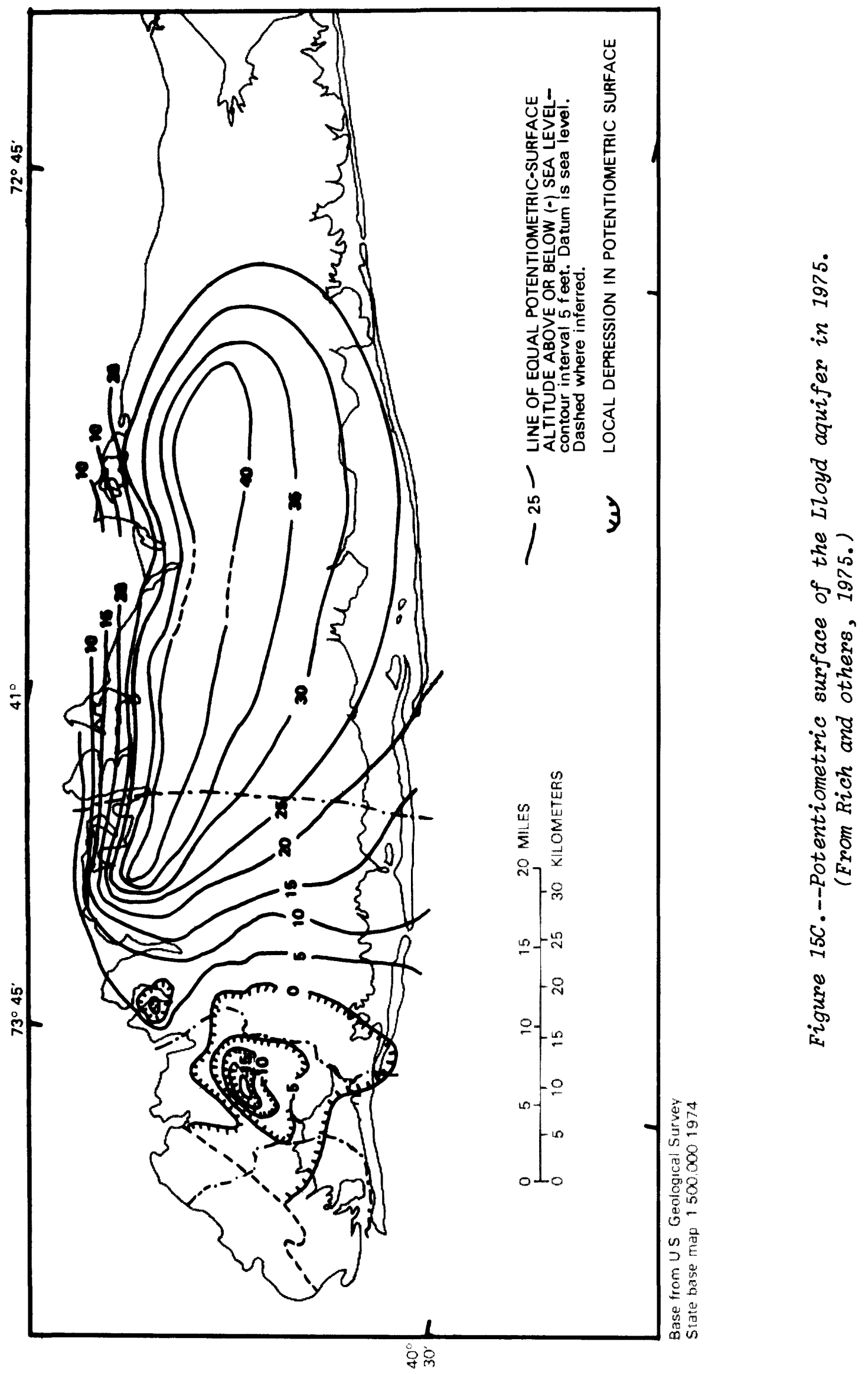




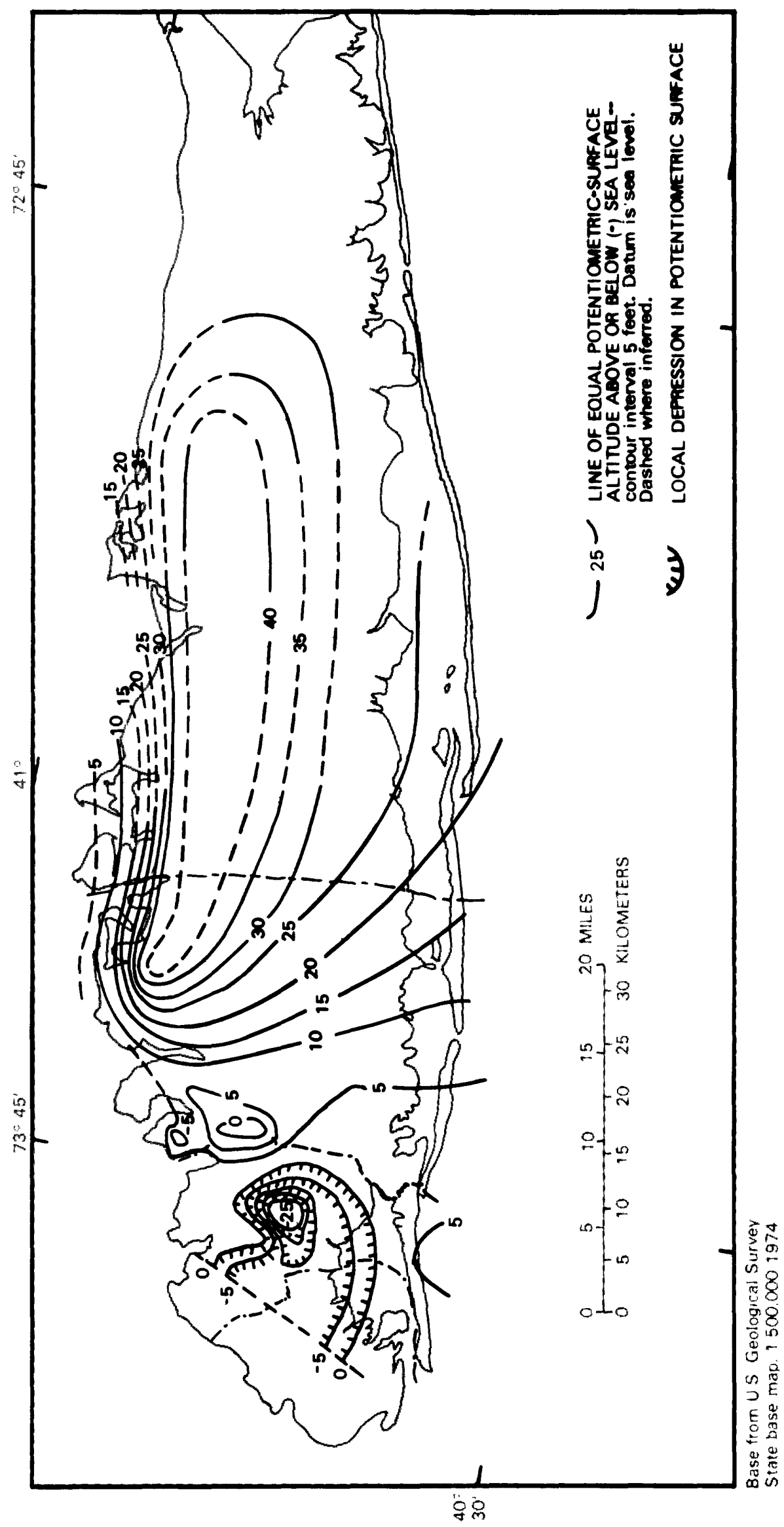

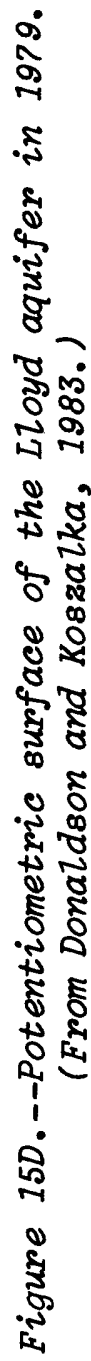




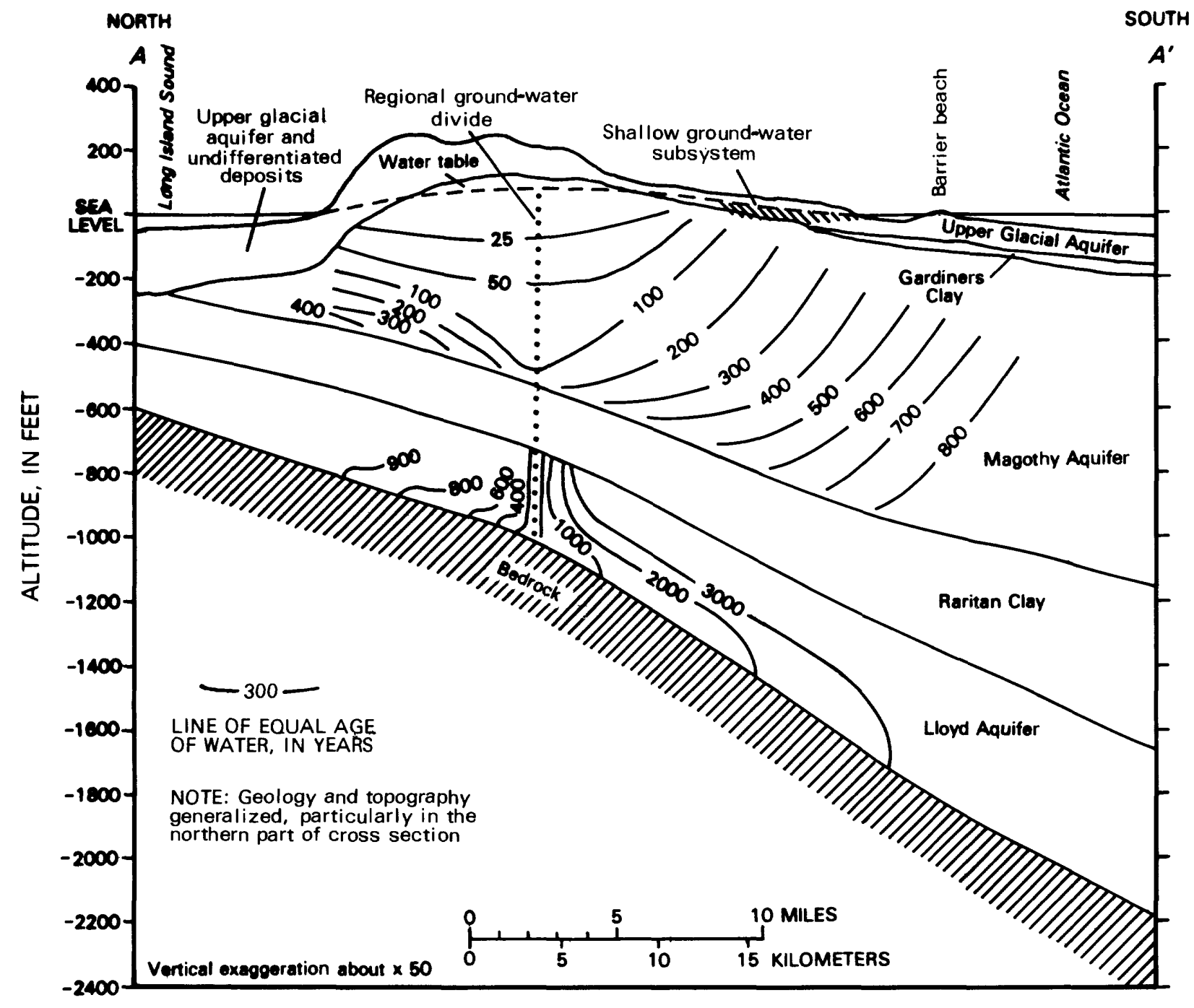

Figure 16.--Approximate time required for water to move from the water table at the ground-water divide to points within the regional ground-water system of Long Island. (Modified from Franke and Cohen, 1972, p. 74.) 


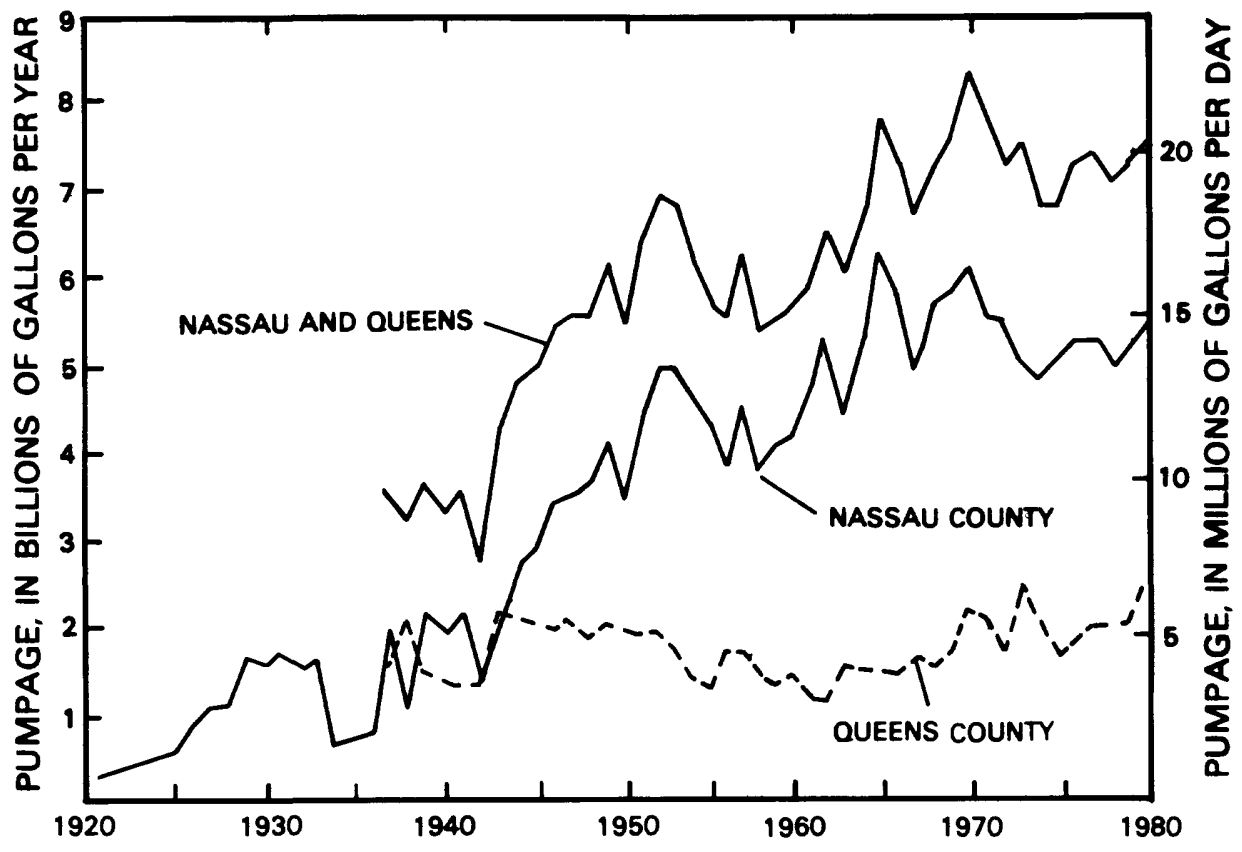

Figure 17.--Annual pumpage from the Lloyd aquifer in Queens and Nassau Counties, 1920-80. (Data from New York State Department of Environmental Conservation, 1982.)

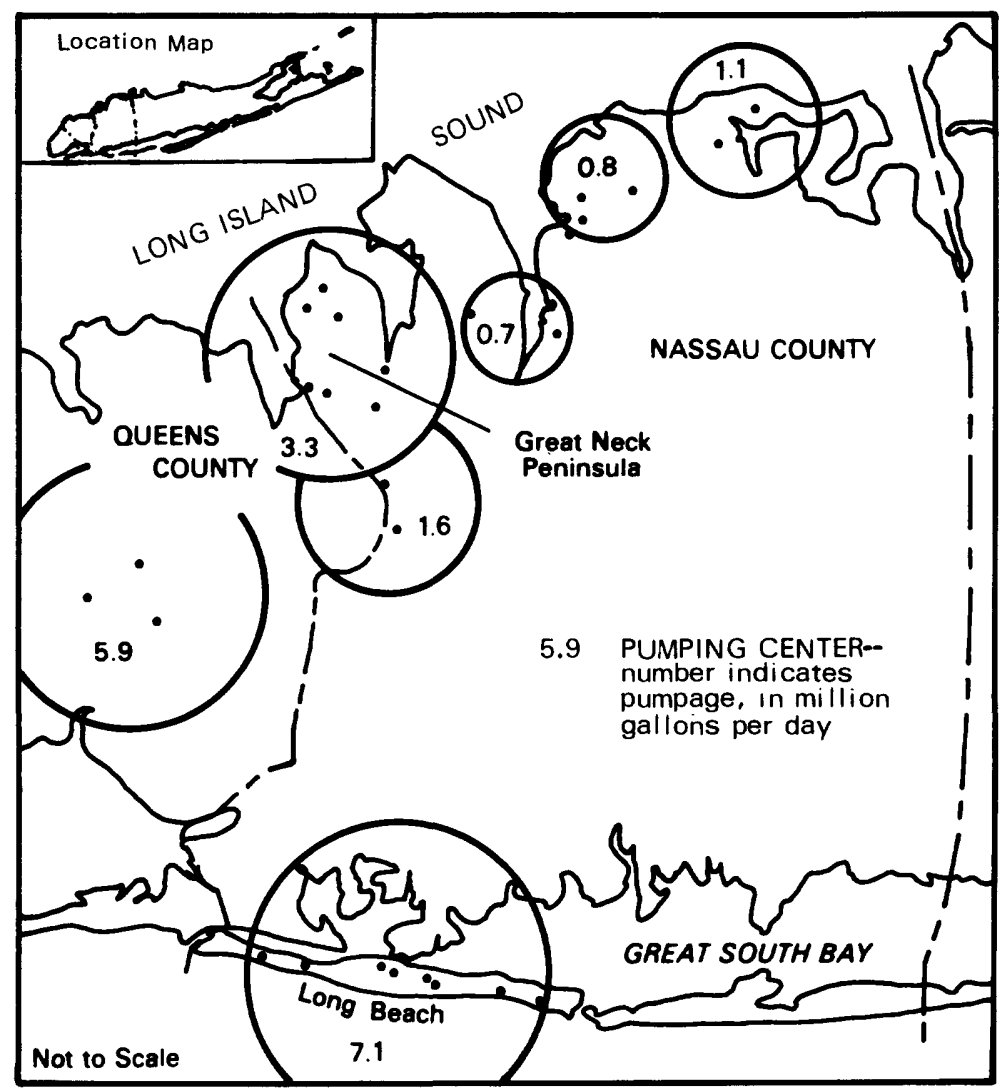

Figure 18.

Areas of significant pumpage from the Lloyd aquifer in Nassau and Queens Counties in 1971. 


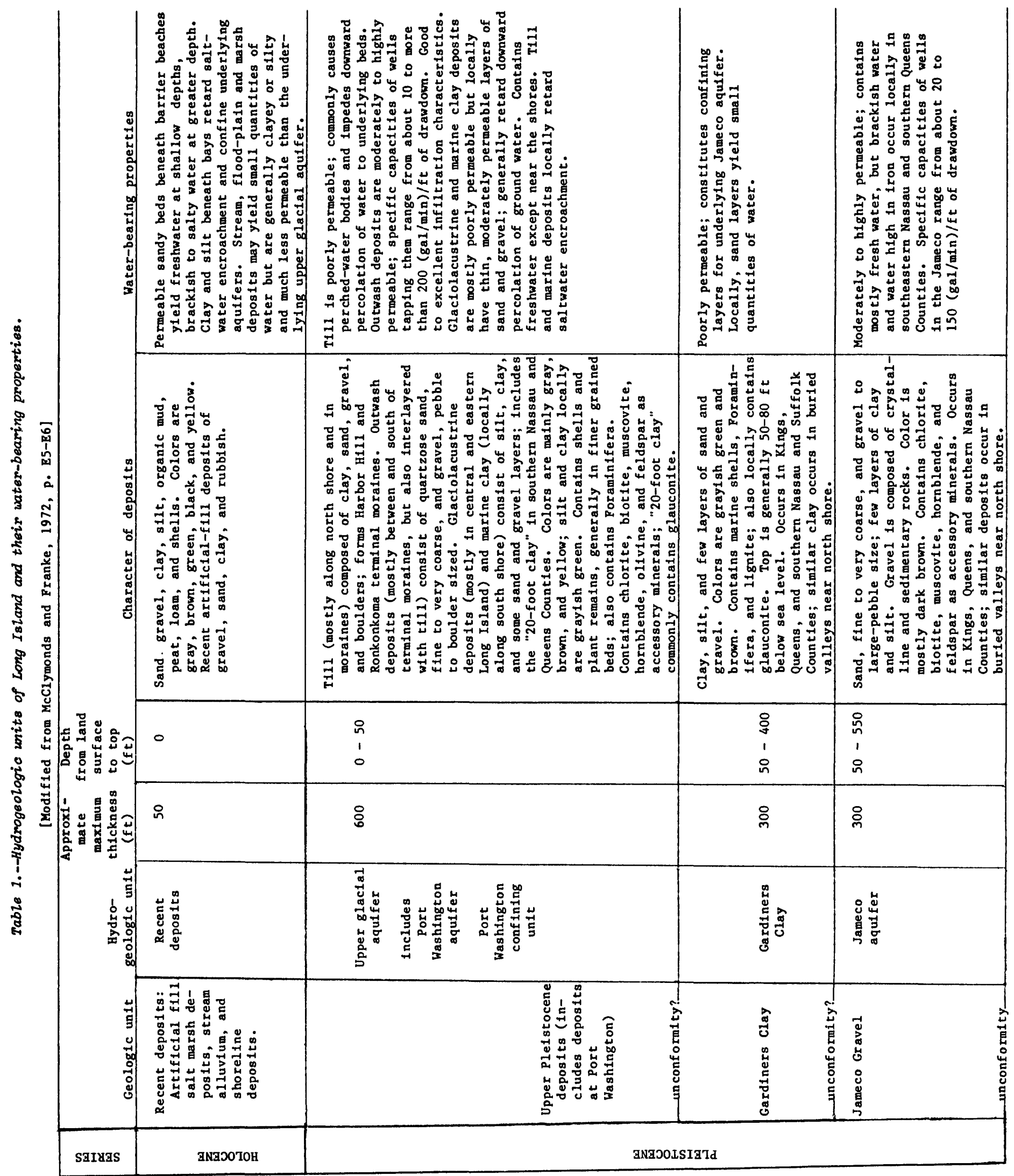




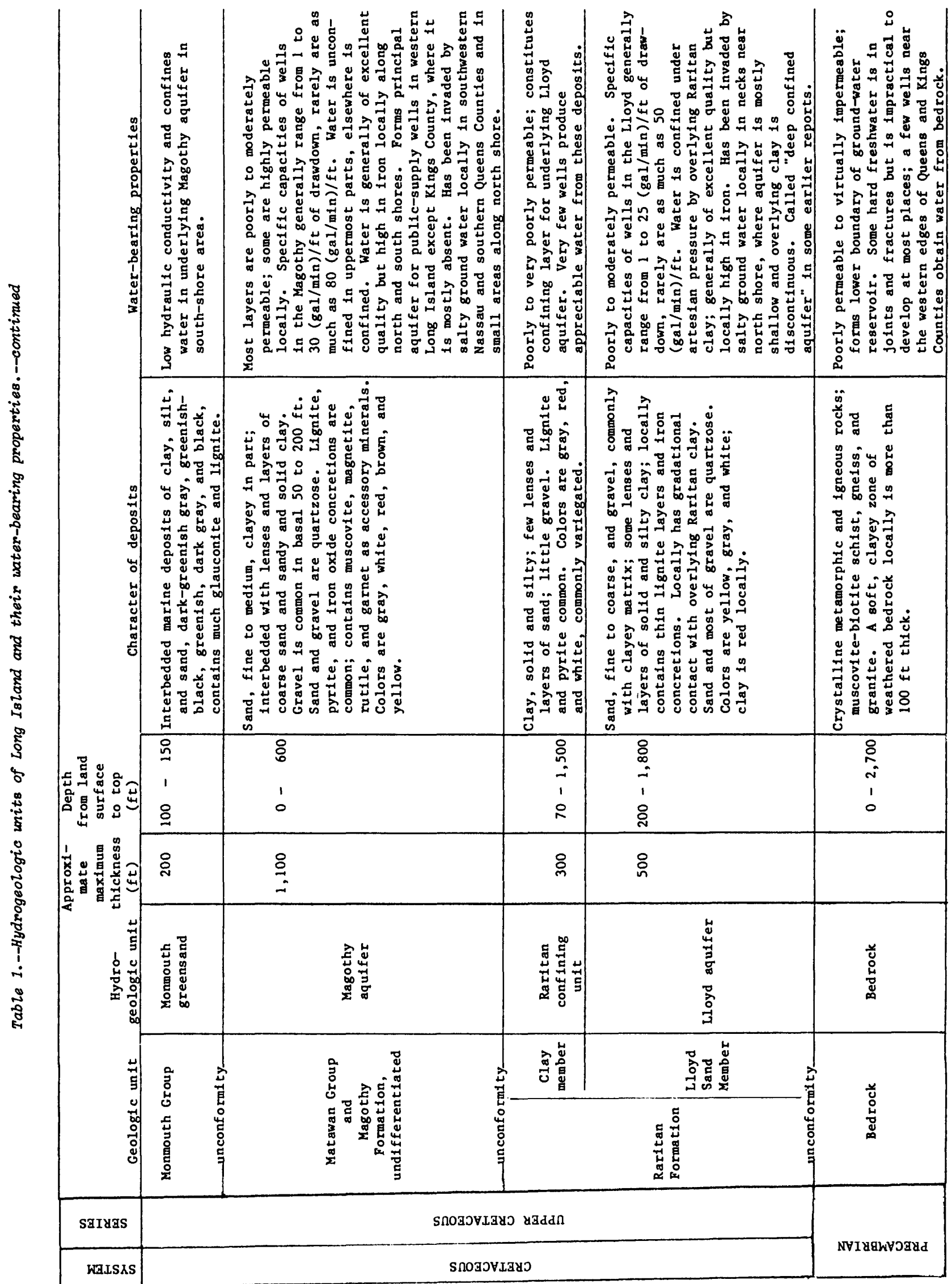




\section{SUMMARY AND CONCLUSIONS}

The Lloyd aquifer, which consists of fine- to coarse-grained sand and gravel with some silt and clay, is the Lloyd Sand Member of the Raritan Formation. The Lloyd underlies most of Long Island at depths ranging from 100 $\mathrm{ft}$ on the north shore to $1,500 \mathrm{ft}$ or more on the south shore. Thickness increases southward and ranges from 50 to $500 \mathrm{ft}$. Transmissivity ranges from about 1,500 to $19,000 \mathrm{ft}^{2} / \mathrm{d}$; the larger value is on the south shore near the border between Nassau and Suffolk Counties, and the smaller value is on parts of the north shore where the Lloyd has been thinned by erosion.

Ground-water flow within the Lloyd aquifer (about $40 \mathrm{Mgal} / \mathrm{d}$ ) is less than 10 percent of the total flow in the Long Island aquifer system. Estimates of ground-water velocities indicate a transit time of about 400 years from the water table to the Lloyd aquifer. Water in the Lloyd beneath the barrier beaches may have been in the aquifer system for 3,000 years. These estimated values indicate that, should the overlying aquifers become contaminated beyond usefulness, the Lloyd will provide a suitable, although limited, source of potable water for many years.

The Lloyd aquifer is confined throughout virtually its entire extent by the overlying clay member of the Raritan Formation. Recharge and discharge occur by vertical flow through this confining layer, although water is also discharged directly into Long Island Sound. Confinement maintains relatively high hydraulic heads in the Lloyd aquifer beneath the barrier beaches along the south shore, where it is generally the only aquifer that yields potable water.

Pumpage from the Lloyd aquifer in central Long Island is legally restricted to protect the coastal water supplies. Total pumpage from the Lloyd aquifer in 1976 was about 7.5 billion gallons (about $20.5 \mathrm{Mga} / \mathrm{d}$ ) and has changed little since 1964. Most pumpage from the Lloyd aquifer is concentrated in few locations in Queens and Nassau Counties; significant drawdown has resulted there, especially in central Queens and in parts of Nassau Counties. 


\section{REFERENCES CITED}

Back, William, and Hanshaw, B. B., 1965, Chemical geohydrology, in Advances in Hydroscience: Chow, Ven te, ed., v. 2, New York, Academic Press, p. 84-93.

Buxton, H. T., Soren, Julian, Posner, Alex, and Shernoff, P. K., 1981, Reconnaisance of the ground-water resources of Kings and Queens Counties, New York: U.S. Geological Survey Open-File Report 81-1186, 59 p.

Cohen, Philip, Franke, 0. L., and Foxworthy, B. L., 1968, An atlas of Long Island's water resources: New York State Water Resources Commission Bulletin 62, $117 \mathrm{p}$.

Cohen, Philip, and Kimmel, G. E., 1971, Status of salt-water encroachment in 1969 in southern Nassau and southeastern Queens Counties, Long Island, New York: U.S. Geological Survey Professional Paper 700-D, p. D281-D286.

Cooper, H. H., Jr., 1959, A hypothesis concerning the dynamic balance of fresh water and salt water in a coastal aquifer: Journal of Geophysical Research, no. 4, p. 461-467.

1964, A hypothesis concerning the dynamic balance of fresh water and salt water in a coastal aquifer, in Sea water in coastal aquifers: U.S. Geological Survey Water-Supply Paper 1613-C, p. 1-11.

Donaldson, C. D., and Koszalka, E. J., 1983a, Potentlometric surface of the Magothy aquifer, Long Island, New York, March 1979: U.S. Geological Survey Open-File Report 82-0160, 2 sheets.

1983b, Potentiometric surface of the Lloyd aquifer, Long Island, New York, in January 1979: U.S. Geological Survey Open-File Report 82-0162, 2 sheets.

Franke, 0. L., and Cohen, Philip, 1972, Regional rates of ground-water movement on Long Island, New York: U.S. Geological Survey Professional Paper $800-C$, p. $\mathrm{C} 271-277$.

Franke, 0. L., and Getzen, R. T., 1976, Evaluation of hydrologic properties of the Long Island ground-water reservoir using cross-sectional analog models: U.S. Geological Survey Open-File Report 75-679, 80 p.

Franke, 0. L., and McClymonds, N. E., 1972, Summary of the hydrologic situation on Long Island, New York, as a guide to water-management alternatives: U.S. Geological Survey Professional Paper 627-F, p. F1-F59.

Fuller, M. L., 1914, The geology of Long Island, New York: U.S. Geological Survey Professional Paper 82, 231 p.

Getzen, R. T., 1977, Analog-model analysis of regional three-dimensional flow in the ground-water reservoir of Long Island, New York: U.S. Geological Survey Professional Paper 982, 49 p.

Grim, M. S., Drake, C. L., Heirtzler, J. R., 1970, Sub-bottom study of Long Island Sound: Geological Society of America Bulletin, v. 81, no. 3, p. 649-665. 


\section{REFERENCES CITED (Continued)}

Heath, R. C., Foxworthy, B. L., and Cohen, Philip, 1966, The changing pattern of ground-water development on Long Island, New York: U.S. Geological Survey Circular 524, $10 \mathrm{p}$.

Hubbert, M. K., 1940, The theory of ground-water motion: Journal of Geology, v. XLVIII, no. 8, part 1, p. 785-944.

Isbister, John, 1962, Relation of fresh water to salt water at Centre Island, Nassau County, New York: U.S. Geological Survey Professional Paper 450-E, art. 226, p. E154-E156.

1966, Geology and hydrology of northeastern Nassau County, Long Island, New York: U.S. Geological Survey Water-Supply Paper 1825, 89 p.

Jacob, C. E., 1940, On the flow of water in an elastic artesian aquifer, in Transactions of the American Geophysical Union: v. 21, p. 574-586.

1941, Notes on the elasticity of the Lloyd sand on Long Island, New York, In Transactions of the American Geophysical Union: v. 22, p. 783-787.

Jensen, H. M., and Soren, Julian, 1974, Hydrogeology of Suffolk County, Long Island, New York: U.S. Geological Survey Hydrologic Investigations Atlas HA-501, 2 sheets.

Kilburn, Chabot, 1980, Hydrogeology of the Town of North Hempstead, Nassau County, Long Island, New York: Nassau County Department of Public Works, Long Island Water Resources Bulletin 12,87 p.

Kimme1, G. E., 1973, Change in potentiometric head in the Lloyd aquifer, Long Island, New York: U.S. Geological Survey Journal of Research, v. 1, no. 3 , p. 345-350.

Koch, E11is, and Koszalka, E. J., 1973, Potentiometric surface of the lower part of the Magothy aquifer in March 1972, Long Island, New York: U.S. Geological Survey Open-File Report, 1 sheet.

Leggette, R. M., 1937, The mutual interference of artesian we11s on Long Island, New York: Transactions of the American Geophysical Union, 18th Annual Meeting, pt. 2, p. 490-494.

Lobeck, A. K., 1939, Geomorphology: New York, McGraw Hil1, 731 p.

Lubke, E. R., 1964, Hydrogeology of the Huntington-Smithtown area, Suffolk County, New York: U.S. Geological Survey Water-Supply Paper 1669-D, p. D1-D68.

Lusczynsk1, N. J., 1952, The recovery of ground-water levels in Brooklyn, New York, from 1947 to 1950: U.S. Geological Survey Circular 167, 29 p.

1961, Head and flow of ground water of variable density: in Journal of Geophysical Research, v. 66, no. 12, p. 4247-4256.

1963, Interface between fresh and salty ground water: U.S. Geological Survey Open-File Report, 12 p. 


\section{REFERENCES CITED (Continued)}

Lusczynski, N. J., Geraghty, J. J., Asselstine, E. S., and Grossman, I. G., 1956, Saline waters in New York State, Long Island, Staten Island, Manhattan, and upstate New York: New York State Water Power and Control Commission Bulletin GW-36, 15 p.

Lusczynsk1, N. J., and Swarzenskf, w. V., 1960, Position of the salt-water body in the Magothy(?) Formation in the Cedarhurst-Woodmere area of southwestern Nassau County, Long Island, New York: Economic Geology, v. 55, p. $1739-1750$.

1962, Fresh and salty ground water in Long Island, New York: American Society of Civil Engineers Proceedings, Journal of the Hydraulics Division, April 1962, v. 88, no. HY 4, p. 173-194.

1966, Salty-water encroachment in southern Nassau and southeastern Queens Counties, Long Island, New York: U.S. Geological Survey Water-Supply Paper 1613-F, p. F1-F76.

Mattick, R. E., and Hennessy, J. L., (eds.), 1980, Structural framework, stratigraphy, and petroleum geology of the area of ofl and gas lease sale no. 49 on the U.S. Atlantic Continental Shelf and Slope: U.S. Geological Survey Circular $812,101 \mathrm{p}$.

McClymonds, N. E., and Franke, O. L., 1972, Water-transmitting properties of aquifers on Long Island, New York: U.S. Geological Survey Professional Paper 627-E, P. E1-E24.

Owens, J. P., Minard, J. P., Soh1, N. F., and Mello, J. F., 1970, Stratigraphy of the outcropping post-Magothy Upper Cretaceous formations in southern New Jersey and northern Delmarva Peninsula, Delaware and Maryland: U.S. Geological Survey Professional Paper 674, 60 p.

Perlmutter N. M., and Crande11, H. C., 1959, Geology and ground-water supplies of the south-shore beaches of Long Island, New York: New York Academy of Science Annals, v. 80, art. 4, p. 1060-1076.

Perlmutter, N. M., and Geraghty, J. J., 1963, Geology and ground-water conditions in southern Nassau and southeastern Queens Counties, Long Island, New York: U.S. Geological Survey Water-Supply Paper 1613-A, p. A1-A205.

Perlmutter, N. M., Geraghty, J. J., and Upson, J. E., 1959, The relation between fresh and salty ground water in southern Nassau and southeastern Queens Counties, Long Island, New York: Economic Geology, v. 54, no. 3, p. 416-435.

Perlmutter, N. M., and Todd, Ruth, 1965, Correlation and Foraminifera of the Monmouth Group (Upper Cretaceous), Long Island, New York: U.S. Geological Survey Professional Paper 483-I, 24 p., 8 pl.

Perry, W. J., Jr., Minard, J. P., Weed, G. A., Robbins, E. I., and Rhodehamel, Edward, 1975, Stratigraphy of Atlantic Coastal Margin of United States North of Cape Hatteras--brief summary: American Association of Petroleum Geologists Bulletin, v. 59/9, p. 1529-1548. 


\section{REFERENCES CITED (Continued)}

Pluhowsk1, E. J., and Kantrowitz, I. H., 1964, Hydrology of the Babylon-Islip area, Suffolk County, Long Island, New York: U.S. Geological Survey Water-Supply Paper 1768, 119 p.

Prince, K. R., 1976, The potentiometric surface of the Magothy aquifer on Long Island, New York, in March 1975: U.S. Geological Survey Open-File Report 76-536, $12 \mathrm{p}$.

Rellly, T. E., and Harbaugh, A. W., 1980, A comparison of analog and digital modeling techniques for simulating three-dimensional ground-water flow on Long Island, New York: U.S. Geological Survey Water-Resources Investigations $80-14,40 \mathrm{p}$.

Rich, C. A., Prince, K. R., and Spinello, A. G., 1975, Potentiometric surface of the Lloyd aquifer on Long Island, New York, in January 1975: U.S. Geological Survey Open-File Report, 12 p.

Sirkin, L. A., 1974, Palynology and stratigraphy of Cretaceous strata on Long Island, New York, and Block Island, Rhode Island: U.S. Geological Survey Journal of -Research, v. 2, no. 4, p. 431-440.

Soren, Julian, 1971a, Ground-water and geohydrologic conditions in Queens County, Long Island, New York: U.S. Geological Survey Water-Supply Paper 2001-A, p. A1-A39.

1971b, Results of subsurface exploration in the Mid-Island area of western Suffolk County, Long Island, New York: Long Island Water Resources Bulletin 1, 60 p.

1978, Subsurface geology and paleogeography of Queens County, Long Island, New York: U.S. Geological Survey Water-Resources Investigations Open-File Report 77-34, $17 \mathrm{p}$.

Suter, Russe11, 1937, Engineering report on the water supplies of Long Island, New York: New York State Water Power and Control Commlssion Bulletin GW-2, 64 p.

Suter, Russe11, de Laguna, Wallace, and Perlmutter, N. M., 1949, Mapping of geologic formations and aquifers of Long Island, New York: New York State Water Power and Control Commission Bulletin GW-18, 212 p.

Swarzenski, W. V., 1959, Ground-water supplies in Pleistocene and Cretaceous deposits of northwestern Nassau County, New York: New York Academy of Science Annals, v. 80, art. 4. p. 1077-1091.

1963, Hydrogeology of northwestern Nassau and northeastern Queens Counties, Long Island, New York: U.S. Geological Survey Water-Supply Paper 1657, 90 p.

Warren, M. A., delaguna, Wallace, and Lusczynsk1, N. J., 1968, Hydrology of Brookhaven National Laboratory and vicinity, Suffolk County, New York: U.S. Geological Survey Bulletin 1156-C, 127 p. 